\title{
Nutrient limitation of phytoplankton in freshwater and marine environments: A review of recent evidence on the effects of enrichment ${ }^{1}$
}

\author{
R. E. Hecky \\ Department of Fisheries and Oceans, Freshwater Institute, 501 University Crescent, Winnipeg, \\ Manitoba R3T 2N6
}

\section{P. Kilham}

Department of Biology and Division of Great Lakes Research, University of Michigan, Ann Arbor 48109

\begin{abstract}
Phytoplankton can become limited by the availability of nutrients when light and temperature are adequate and loss rates are not excessive. The current paradigms for nutrient limitations in freshwater, cstuarine, and marine environments are quite different. A review of the experimental and observational data used to infer $\mathrm{P}$ or $\mathrm{N}$ limitation of phytoplankton growth indicates that $\mathrm{P}$ limitation in freshwater environments can be demonstrated rigorously at several hierarchical levels of system complexity, from algal cultures to whole lakes. A similarly rigorous demonstration of $\mathrm{N}$ limitation has not been achieved for marine waters. Therefore, we conclude that the extent and severity of $\mathrm{N}$ limitation in the marine environment remain an open question. Culture studies have established that internal cellular concentrations of nutrients determine phytoplankton growth rates, and these studies have shown that it is often difficult to relate growth rates to external concentrations, especially in natural situations. This should lead to a greater reliance on the composition of particulate matter and biomass-based physiological rates to infer nutrient limitation. Such measurements have demonstrated their utility in a wide variety of freshwater and marine environments, and, most importantly, they can be applied to systems that are difficult to manipulate expcrimentally or budget accurately. Dissolved nutrient concentrations are most useful in determining nutrient loading rates of aquatic ecosystems. The relative proportions of nutrients supplied to phytoplankton can be a strong selective force shaping phytoplankton communities and affecting the biomass yicld per unit of limiting nutrient.
\end{abstract}

A current dogma of aquatic science is that marine and estuarine phytoplankton tend to be nitrogen limited, while freshwater phytoplankton tend to be phosphorus limited. Carpenter and Capone (1983) documented the preeminence of $\mathrm{N}$ studies in the literature on brackish and marine ecosystems. In 1970 there were equal numbers of references per year to $\mathrm{N}$ and $\mathrm{P}$. The decade of the seventies saw a nearly fourfold increase in references to $\mathrm{N}$, while the number of $P$ references per year remained essentially unchanged. No trend was evident for the freshwater literature despite the fact that by the late seventies the evidence for $\mathbf{P}$ limitation had become so great that phosphorus control was recommended as the legislated basis for controlling eutrophication in North American and Europcan inland waters (e.g.

' S. V. Smith, D. W. Schindler, F. P. Healey, G. J. Brunskill, K. Patalas, E. J. Fee, and P. Campbell provided comments and suggestions on this manuscript.
Rast and Lee 1978; Janus and Vollenweider 1981).

A fundamental dichotomy in nutrient limitation in fresh and salt-water ecosystems is somewhat unexpected since the nutritional requirements of phytoplankton of such ecosystems are similar. Also, the fact that phytoplankton can deplete required nutrients to undetectably low concentrations in both of these environments suggests that there is no fundamental difference in the affinity of phytoplankton for the required nutrients. No biogeochemical processes that might limit availability of $\mathrm{N}$ or $\mathrm{P}$ to phytoplankton are known to be unique to onc of these environments. Rather, explanations tend to emphasize differences in scale; for example, $\mathrm{N}$ fixation is slow in the ocean or denitrification is fast relative to their rates in freshwater environments. In fact, much research today is directed toward explaining why marine and freshwaters might differ in their limiting nutrient (Smith 1984; How- 
Table 1. Elemental composition of algae (from Healey 1973).

\begin{tabular}{lccr}
\hline & \multicolumn{2}{c}{ Dry weight $(\mu \mathrm{g}$ mg ') } & \\
\cline { 2 - 3 } Elcment & Avg & \multicolumn{1}{c}{ Range } & Relative atoms \\
\hline $\mathrm{H}$ & 65 & $29-100$ & $8,140,000$ \\
$\mathrm{C}$ & 430 & $175-650$ & $4,460,000$ \\
$\mathrm{O}$ & 275 & $205-330$ & $2,120,000$ \\
$\mathrm{~N}$ & 55 & $10-140$ & 487,000 \\
$\mathrm{Si}$ & 54 & $0-230$ & 237,000 \\
$\mathrm{~K}$ & 17.3 & $1-75$ & 55,000 \\
$\mathrm{P}$ & 11 & $0.5-33$ & 43,800 \\
$\mathrm{Na}$ & 6.1 & $0.4-47$ & 32,500 \\
$\mathrm{Mg}$ & 5.6 & $0.5-75$ & 28,700 \\
$\mathrm{Ca}$ & 8.7 & $0.0-80$ & 27,500 \\
$\mathrm{~S}$ & 5.9 & $1.5-16$ & 23,800 \\
$\mathrm{Fe}$ & 5.9 & $0.2-34$ & 13,800 \\
$\mathrm{Zn}$ & 0.28 & $0.005-1.0$ & 540 \\
$\mathrm{~B}$ & 0.03 & $0.001-0.25$ & 350 \\
$\mathrm{Cu}$ & 0.10 & $0.006-0.3$ & 200 \\
$\mathrm{Mn}$ & 0.06 & $0.02-0.24$ & 138 \\
$\mathrm{Co}$ & 0.06 & $0.0001-0.2$ & 125 \\
$\mathrm{Mo}$ & 0.0008 & $0.0002-0.001$ & 1 \\
\hline
\end{tabular}

arth and Cole 1985; Paerl 1985; Smith et al. 1986). This review will take a different approach and examine the evidence and rationale used to establish nutrient limitation in aquatic environments. It will show that differences between views of marine and freshwater scientists on nutrient limitation are perhaps based more on technique and inference than on any fundamental difference in ecology. Smith (1984) has previously raised this possibility.

\section{Nutritional requirements of phytoplankton}

Algal cells require elements in relatively fixed proportions in order to reproduce. Table 1 lists elements required by at least some algae (e.g. not all species require $\mathrm{Si}$ ). Despite often large interspecies variation, it is possible to consider a mean nutrient composition for algal cells growing without nutrient limitation (Goldman 1980; Healey 1978). A relatively narrow range of elemental composition has presumably evolved because all algal cells have to perform similar metabolic functions and have qualitatively similar structural requirements. Given that the biochemical role of each element is unique (i.e. only limited substitution is possible), there are stoichiometric requirements to be met in the growth of any species of algae.
Table 2. Relative elemental composition of algae (normalized on total dissolved $P$ on a molar basis) compared to the relative mean composition of the dissolved constituents of river water and ocean water. Underlined values are similar in abundance to algal requirements (relative to $P$ ) or scarcer. Values in parentheses are highly uncertain.

\begin{tabular}{|c|c|c|c|}
\hline \multirow[b]{2}{*}{ Element } & \multicolumn{3}{|c|}{ Relative composition } \\
\hline & River* & Algal $\dagger$ & Occan $\ddagger$ \\
\hline $\mathbf{H}$ & & 186 & \\
\hline $\mathrm{C}$ & 738 & 102 & 1,000 \\
\hline $\mathrm{O}$ & & 48 & \\
\hline $\mathbf{N}$ & $28[21] \S$ & 11.1 & 13 \\
\hline $\mathrm{Si}$ & 146 & $96 \|$ & $\overline{43}$ \\
\hline $\mathbf{K}$ & 26 & 1.3 & 4,434 \\
\hline $\mathbf{P}$ & 1.0 & 1.0 & 1.0 \\
\hline $\mathrm{Na}$ & $16 \overline{9}$ & 0.74 & $200,00 \overline{0}$ \\
\hline $\mathrm{Mg}$ & 123 & 0.66 & 23,000 \\
\hline $\mathrm{Ca}$ & 28 & 0.63 & 4,480 \\
\hline $\mathbf{S}$ & 146 & 0.54 & 12,000 \\
\hline $\mathrm{Fe}$ & 0.55 & 0.32 & $(0.0004)$ \\
\hline $\mathrm{Zn}$ & $\overline{0.35}$ & 0.012 & 0.003 \\
\hline B & 0.13 & 0.008 & $18 \overline{2}$ \\
\hline $\mathrm{Cu}$ & 0.12 & 0.004 & 0.002 \\
\hline Mn & 0.12 & 0.003 & 0.002 \\
\hline $\mathrm{Co}$ & $\underline{0.003}$ & 0.003 & $(\overline{0.00001)}$ \\
\hline Mo & $\overline{0.004}$ & 0.00002 & 0.048 \\
\hline
\end{tabular}

* Ratios arc calculated from the following sources: Meybeck 1982 for $P$ and $N$ concentrations; Livingstone 1963 for S and C; Martin and Meybeck 1979 for the remaining concentrations.

† Healcy 1973.

† Broccker and Peng 1982.

$\$$ Bracketcd value is based on total dissolved inorganic fixed $N$ and total dissolved inorganic $P$.

|| Parsons et al. 1961 and Reynolds 1984; requirement is for diatoms only.

If mean river water or mean ocean water were used as a source water for growing a culture of a species of mean composition (Table 2), then relatively few of the elements required for growth would likely become limiting. Only $\mathrm{P}, \mathrm{Fe}$, and $\mathrm{Co}$ in river water and $\mathrm{P}, \mathrm{N}, \mathrm{Si}, \mathrm{Fe}, \mathrm{Zn}, \mathrm{Cu}, \mathrm{Mn}$, and $\mathrm{Co}$ in seawater are present in relative proportions similar to or less than those required by phytoplankton. All other elements would be available in excess. Limitation by trace metals has received neither the attention that the macronutrients $\mathrm{P}, \mathrm{N}$, and $\mathrm{Si}$ have, nor perhaps as much as it should (Table 2). Although recent research has established that the availability of metals has been a selective factor in the evolutionary ecology of marine phytoplankton (Brand et al. 1983) and has been invoked as possibly growthlimiting in some marine and freshwater 
situations, the subject will not be treated further here due to the relative paucity of information on trace metals compared to that on the macronutrients $\mathrm{C}, \mathrm{N}, \mathrm{Si}$, and $\mathrm{P}$.

Deviations from mean dissolved nutrient concentrations are the rule in both freshwater and marine ecosystems. In marine systems and lakes, biologically active elements are constantly being removed from surface waters by nutrient uptake and sedimentation and are being added by mixing with river water or with deeper water from the aphotic zone. There are other biogeochemical processes (e.g. denitrification, $\mathrm{N}$ fixation, $\mathbf{P}$ adsorption, cultural eutrophication, etc.) that can selectively remove or enrich nutrients and create local anomalies in the relative proportions of the essential elements. The significance of the data in Table 2 is that it quickly reduces the number of elements likely to limit algal growth in most aquatic environments. On average, in freshwater situations $P$ is the most likely of the macronutrients to become limiting to algal growth, while in marine systems $\mathrm{P}, \mathrm{Si}$, and $\mathrm{N}$ are all possible candidates.

\section{The concept of limitation}

Natural phytoplankton communities are composed of populations of species. For these species to persist through time, their cellular growth rate $\left(k^{\prime}\right)$ must exceed or equal losses to dilution $\left(k_{w}\right)$, sedimentation $\left(k_{s}\right)$, physiological death $\left(k_{d}\right)$, and grazing $\left(k_{g}\right)$, as shown in Eq. 1 [terminology from Reynolds (1984)]:

$$
\begin{aligned}
\mathrm{d} N / \mathrm{d} t & =k^{\prime} N-k_{w} N-k_{s} N-k_{d} N-k_{g} N \\
N_{t} & =N_{0} \exp \left(k^{\prime}-k_{w}-k_{s}\right. \\
- & \left.k_{d}-k_{g}\right) t .
\end{aligned}
$$

The term $\mathrm{d} N / \mathrm{d} t$ is the population growth rate, $N$ the abundance of a phytoplankton species, $N_{t}$ the population biomass at time $t$, and $N_{0}$ the biomass at time zero. $N$ and $\mathrm{d} N / \mathrm{d} t$ are determined by $k^{\prime}$ and the sum of the loss terms. An increase in abundance can be generated by increasing $k^{\prime}$ or decreasing one or more of the loss terms. Consequently, any single species can be limited (i.e. prevented from increasing) by its growth coefficient, its loss terms, or both. It is im- portant to realize that population increases can occur at both low and high $k^{\prime}$; therefore, a low abundance does not mean that the cellular growth rate, $k^{\prime}$, is limited in any way. Phytoplankton communities are made up of species populations, each of which is achieving (or achicved in the recent past) a null or positive solution to Eq. 1 but perhaps in very different ways.

Nutrients affect Eq. 1 directly through $k^{\prime}$, which is a function of light, temperature, and nutrient supply. Nutrient-limited growth can be modeled using either the Droop model or the Monod model. The Droop model (1974) of phytoplankton growth relates growth rates to internal nutrient concentrations. This model is considered to provide a reasonable representation of nutrient-limited algal growth, and its utility at the natural, community level has been established (e.g. Jones et al. 1978). The Monod equation relates phytoplankton growth to external concentrations of dissolved nutrients. Both relationships have their strengths and weaknesses (see Kilham and Hecky 1988). Application of the Monod model is limited by current analytical methods, which often cannot measure the very low dissolved nutrient concentrations that have been shown to limit growth. The successful use of the Droop equation to describe nutrient-limited growth should encourage aquatic ecologists to study the nutrient composition of particulate matter in order to address questions of nutrient limitation and the relative growth rates of phytoplankton communities.

In unialgal chemostat cultures, precise definition of the cellular growth rate is possible after steady state is achieved. The growth rate equals the dilution rate, and, by controlling the culture medium composition and rate of addition, any nutrient can be made limiting when light and temperature are adequate. In a P-limited chemostat, the cellular growth rate will be proportional to the cellular concentration of $P$ (Fig. 1) as predicted by the Droop model and observed by numerous researchers (e.g. Rhee 1974; Perry 1976; Sakshaug and Holm-Hansen 1977; Goldman et al. 1979). Nutrient limitation imposes other compositional and 
physiological changes on the cells. Some of these are specific to a given nutrient, while others are general responses to nutrient limitation of any kind (Healey 1975; Healey and Hendzel 1980). Healey (1978) found that species of chlorophytes, cyanophytes, diatoms, chrysophytes, and dinoflagellates had similar internal nutrient concentrations and physiological responses when they were growing at similar relative growth rates under $\mathrm{P}$ or $\mathrm{N}$ limitation (Fig. 2). Goldman (1980) expressed the same conclusion for marine phytoplankton (Table 3 ).

Contemporaneous multiple nutrient limitation has not been shown for any unialgal culture (Droop 1974; Rhee 1978; Kilham and Kilham 1984), and theoretically it would not be expected, since the macronutrients cannot substitute for each other in their biochemical functions (Droop 1974; Rhee 1978; Healey 1985). However, nutrients can compensate, within limits, for physical limitations-c.g. light and temperature, and vice versa-so that co-limitation by a physical factor and a nutrient is demonstrable in unialgal chemostats (Hcalcy 1985). In multiple-species chemostats, multiple nutrient limitation of phytoplankton growth has been demonstrated both theoretically (Petersen 1975; Tilman 1977) and empirically (Tilman 1977; Tilman et al. 1982). This can occur because species differ in their optimum nutrient ratios for growth (Tables 4 and 5). Deviance from the optimum nutrient ratio can lead to limitation by one or the other nutrient. For example, Tilman (1977) demonstrated experimentally in chemostat cultures that Asterionella formosa dominated at $\mathrm{Si}: \mathrm{P}$ ratios $>100$, while $C y$ clotella meneghiniana dominated at $\mathrm{Si}: \mathrm{P}$ $<10$ (Fig. 3). At intermediate ratios, the species coexisted since each was limited by either $\mathrm{Si}(A$. formosa) or $\mathrm{P}$ (C. meneghiniana). Therefore, nutrient-loading ratios can exert a strong selective effect on natural communities of phytoplankton and, in turn, can affect the biomass yield for the nutrient limiting most species (Smith 1982). When nonsteady state conditions are imposedfor example, by pulsing nutrients (Sommer 1985)-even more species can be supported as the kinetics of nutrient uptake, which can

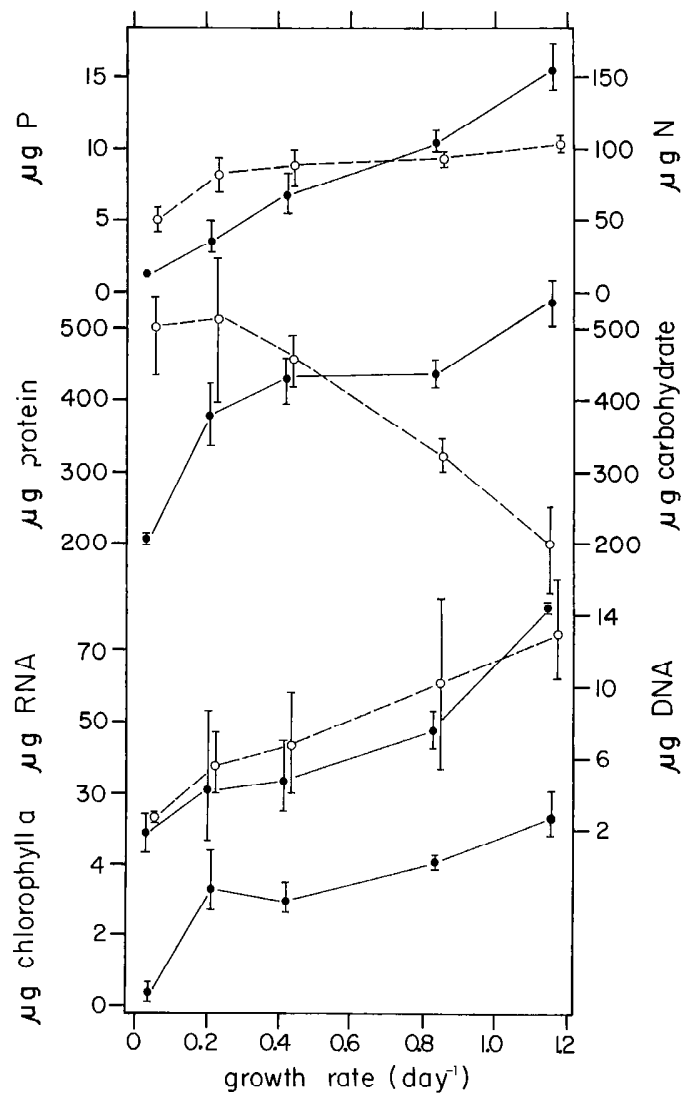

Fig. 1. Effect of growth rate in a P-limited chemostat on the composition of Anabaena variabilis. Refer to axes on the left-hand side; $O-$ refer to the right-hand side. Values expressed as $\mu \mathrm{g} \mathrm{mg}^{-1}$ dry weight. Vertical bars indicate the range of values; symbol indicates average (from Healey 1978).

be uncoupled from growth, allow specics that are limited by the same nutrient to persist.

Based on our knowledge of the kinetics of algal growth and population dynamics (Eq. 1), it is possible to conceive of a natural phytoplankton assemblage in which one or more species are limited by a common nutrient for which they are competing, different nutrients, light, temperature, light or temperature and a nutrient, one or more of their various loss terms, a nutrient and one or more of their various loss terms, and a number of non-nutrient factors (e.g. toxic substances, osmotic stress, etc.) not considered here. Given such potential complexity, 


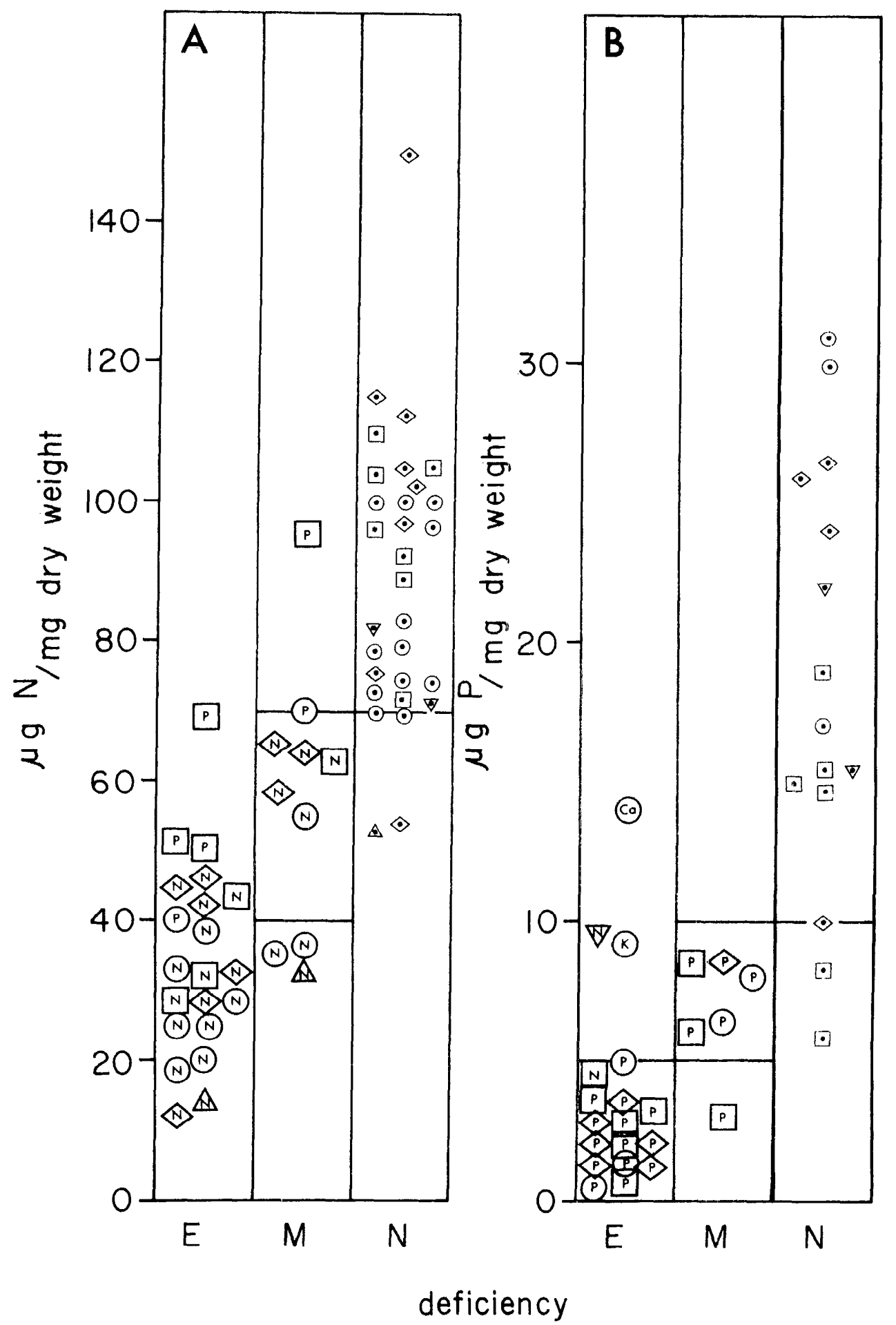

Fig. 2. The $\mathrm{N}$ and $\mathrm{P}$ contents of cultured algae as a function of nutrient deficiency. Each data point represents a single value taken from published literature. $\mathrm{N}, \mathrm{P}$, or $\mathrm{K}$ indicates the deficient nutrient; a dot indicates no deficiency. The symbol around each data point indicates the class of the alga studied: $O-$ chlorophyte; $\square-$ cyanophyte; $\diamond-$ diatom; $\triangle$-chrysophyte; $\nabla-$ dinoflagellate. $E$ is extreme, $M$ is moderate, and $N$ is no deficiency (from Healey 1978). 
Table 3. Typical cellular chemical ratios of phytoplankton at low and high proportions of maximum growth rate $(\mu)$ (from Goldman 1980).

\begin{tabular}{lcc}
\hline \hline Cellular ratio & $<0.1 \mu$ & $>0.9 \mu$ \\
\hline C: N (atoms) & $20-25$ & $5-7$ \\
C:P (atoms) & $500-1,000$ & $75-150$ \\
N:P (atoms) & $100-150$ & $10-20$ \\
C:Chl (wt) & $100-150$ & $25-50$ \\
\hline
\end{tabular}

the only true statement that can be made about all the phytoplankton populations is that they are-or, given their capacity for exponential increase, soon must be-limited by something. It is simplistic to assume that all the species in a community are limited by a single factor. In fact, phytoplankton communities are complex mixtures of species with highly individualistic life-history characteristics, especially in regard to meeting their nutrient requirements (Kilham and Hecky 1988). However, practical aspects of the effects of nutrient enrichment generally focus on the total biomass of phytoplankton produced rather than on the production of any single species, even though nuisance blooms are often nearly monospecific. Consequently, the relevant questions are: Can the growth of the natural phytoplankton community be increased (or decreased) significantly by the addition (or deletion) of one or more nutrients? Which nutrient has the greatest effect? These questions have focused interest on aggregate variables like primary production and algal biomass (or a surrogate such as chlorophyll

Table 4. Optimum $\mathrm{N}: \mathrm{P}$ atomic ratios for some freshwater and marine phytoplankton (from Smith 1982 and Kilham and Kilham 1984).

\begin{tabular}{cl}
\hline \hline $\mathrm{N}: \mathrm{P}$ & \multicolumn{1}{c}{ species } \\
\hline 87 & Scenedesmus quadricauda \\
39 & Cryptomonas erosa \\
30 & Scenedesmus obliquus \\
28 & Oscillatoria agardhii \\
25 & Fragilaria crotonensis \\
24 & Chaetoceros affinis \\
23 & Selenastrum capricornutum \\
21 & Ankistrodesmus falcatus \\
21 & Pseudoanabaena catenata \\
12 & Skeletonema costatum \\
12 & Asterionella formosa \\
10 & Synedra ulna \\
9 & Microcystis sp. \\
7 & Melosira binderana \\
\hline
\end{tabular}

Table 5. Optimum Si:P atomic ratios for freshwater diatom species. Relative position is indicated for some species for which absolute values have been left blank because they are yet to be defined (from Kilham and Kilham 1984).

\begin{tabular}{cl}
\hline \hline Si:P & \multicolumn{1}{c}{ Specics } \\
\hline & Synedra filiformis \\
& Fragilaria crotonensis \\
$96-93$ & Asterionella formosa \\
& Tabellaria flocculosa \\
& Diatoma elongatum \\
& Melosira italica \\
& Fragilaria capucina \\
& Stephanodiscus hantzschii \\
& Cyclotella meneghiniana \\
& Stephanodiscus minutus \\
& Stephanodiscus astraea \\
\hline
\end{tabular}

concentration) and their response to nutrient enrichment.

\section{Evidence for nutrient limitation}

Dissolved nutrient concentrations were the earliest data used to infer nutrient limitation. This was based largely on negative evidence; for example, the fact that dissolved nitrate usually became unmeasurable bcfore phosphate in seawater predisposed marine biologists as early as the turn of the century (reviewed by Nixon and Pilson 1983) to infer that $\mathrm{N}$ was more likely than $\mathbf{P}$ to limit algal production. However, there are numerous phytoplankton species and communities that have such high affinities for $\mathrm{N}$ and $\mathrm{P}$ that nutrient limitation, if it occurs, occurs at concentrations not an-

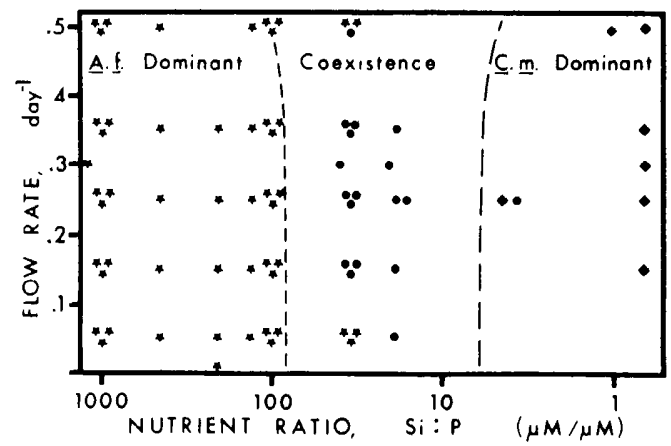

Fig. 3. The steady state results of 76 long-term competition experiments compared with the predictions. $\star-$ Cultures in which Asterionella formosa $(A . f$.) was compctitively dominant; - cultures in which Cyclotella meneghiniana (C.m.) was dominant; stable coexistence of both species (from Tilman 1977). 
alytically detectable (Brown and Button 1979; Goldman and Glibert 1983). Consequently, dissolved nutrient data cannot be interpreted in terms of growth limitation given present analytical capabilities.

Nutrient concentration data can be used to calculate fluxes of nutrients to algal cultures and aquatic ecosystems. If algal growth can be shown to be more dependent on one nutrient flux than any other, then that nutrient may limit algal growth. In nutrientlimited chemostats at a constant dilution rate, algal yield is directly proportional to the input of the limiting nutrient. This analogy has been usefully extended to lakes, initially by Vollenweider (1968). Control of phosphorus input is now the basis for management of lake eutrophication in many parts of the world. If we are to calculate reasonably precise nutrient supply rates, the system of interest must have well-defined boundaries and all nutrient inputs must be measured. Consequently, the concept is more difficult to apply to oceans and estuaries, although it has been applied to coastal bays (Smith 1984) and some estuaries (e.g. Jaworski 1981; Nixon 1981; Lee and Jones 1981; Nixon and Pilson 1983).

Chemical composition and physiological measurements have been used in both freshwater (e.g. Healey and Hendzel 1980; Vincent et al. 1984; Zevenboom et al. 1982) and marine situations (Sakshaug and Olsen 1986; Yentsch et al. 1977; Goldman et al. 1979) to determine if phytoplankton are nutrient limited. One experimental basis for such measurements is the Droop model, in which the internal stores of nutrients determine nutrient uptake and growth rates. But, in general, algae from diverse groups have remarkably similar physiological and compositional responses to nutrient limitation (Healey 1973); thus, such responses are useful indicators of nutrient status. Measurements of nutrient status have the advantage that they can be performed on natural assemblages (i.e. prolonged incubations are not required). However, these observations are essentially instantaneous, so repetitive sampling may be required to characterize the general state of the ecosystcm.

Nutrient enrichment bioassays have been widely applied to both freshwater and ma- rine systems for experimental hypothesis testing of nutrient limitation. A nutrient enrichment bioassay is an operational test for nutrient limitation in which one or more nutrients is added to a volume of water to determine if algal growth is stimulated. Unfortunately, the test result is likely to be dependent on the test system. For example, many nutrient enrichment assays have been performed in which the only natural component is the water and its dissolved constituents because a cultured algal species is used as a test organism. At the other extreme of system size and complexity, experimental nutrient additions have been made to whole lakes. For convenience, four levels of test system organization can be recognized (Tablc 6). Higher level systems, especially natural systems, are capable of much more complex responses at longer time scales. The only level of concern to aquatic resource managers is the highest level, but inferences are often made based on evidence from lower level test systems. As Droop (1977) has emphasized, the proof of a model's validity at onc level of natural organization implies validity, but not necessarily applicability, in all higher levels. Several examples are given below. It is axiomatic that the higher the level of the expcrimental test, the more applicable it is likely to be to the natural situation of interest.

Increasing the "naturalness" of test systems means decreasing the experimenter's control of them. In a level I experiment, full control, in the sense that the experimenter determines their value, can be taken of nearly all parameters contributing to the population growth (Table 7). The configuration of lower level systems can impose a nutrient limitation, by eliminating many natural fluxes and reducing loss terms, when none or a different one exists in the natural system. In contrast, at level IV the experimenter sets very few parameter values. Controls for these high level experiments are comparative systems assumed to be similar in all respects except the nutrient enrichment of interest. Statistical treatment of data from level I systems can be quite rigorous, whereas statistical treatment of level IV experiments can be awkward (Hurl- 
Table 6. Different levels of organization for systems containing algal populations. Components in parentheses may not be present in any particular system; e.g. the culture media may be changed (renewed) or not during the course of a level I experiment.

\begin{tabular}{|c|c|c|c|c|}
\hline Level & Gencric name & System components & Time scale & $\operatorname{Sizc}\left(\mathrm{m}^{\prime}\right)$ \\
\hline I & Culture & $\begin{array}{l}\text { Cultured algae } \\
\text { Water/medium } \\
\text { (+ renewal) }\end{array}$ & hours-days & $10^{3}-10^{\circ}$ \\
\hline II & Community culture & $\begin{array}{l}\text { Natural algal community } \\
\text { Water/medium } \\
\text { (+ renewal) } \\
\text { (+ microheterotrophs) }\end{array}$ & days & $10^{3}-10^{1}$ \\
\hline III & Enclosure; mesocosm & $\begin{array}{l}\text { Natural algal community } \\
\text { Water/medium } \\
\text { Microheterotrophs } \\
\text { Macrozooplankton } \\
\text { (+ renewal) } \\
\text { (+ atmospheric exchange) } \\
\text { (+ sediment exchangc) } \\
\text { (+ small fish) }\end{array}$ & days-months & $10^{-3}-10^{3}$ \\
\hline IV & Rivers, lakes, bays, oceans & $\begin{array}{l}\text { Natural algal community } \\
\text { Water/medium } \\
\text { Microheterotrophs } \\
\text { Macrozooplankton } \\
\text { Renewal } \\
\text { Atmospheric exchange } \\
\text { Sediment exchange } \\
\text { Fish populations } \\
\text { Intrasystem nutrient exchange } \\
\text { Floral and faunal exchange } \\
\text { Evolutionary change }\end{array}$ & months-millennia & $10^{6}-10^{88}$ \\
\hline
\end{tabular}

bcrt 1984). Consequently, level IV results must be very clear results. Fine statistical differences are not likely to impress resource managers facing decisions about expensive water treatment or restoration programs. Two important questions emerge from such considerations. First, what is the minimum acceptable level of test system from which experimental interpretations can safely be extrapolated to natural systems? Second, are existing dogmas of nutrient limitation in freshwater and marine systems based on similar evidence?

Freshwater and marine systems differ in the efficacy with which the different lines of evidence can and have been applied. The nutricnt supply concept is frequently applied to freshwater systems, but it is relatively rare in marine systems (Nixon and Pilson 1983). The nutrient enrichment bioassay has been applied to almost all aquatic systems, but there are many more mesocosm and whole-system studies of nutrient limitation in freshwater than in marine waters. The only approach that can be equally well applied in both is compositional and physiological analyses of the phytoplankton. The obvious question is whether these different approaches converge on the same conclusion about nutrient limitation when they are all applied to the same ecosystem. A freshwater and a marine ecosystem that have been studied by at least level III nutrient enrichment experiments and that have been the subject of lower levels of investigation are reviewed below to answer this question.

\section{Freshwater-The Experimental Lakes Area}

In northwestern Ontario, the Experimental Lakes Area (ELA) was the site of several whole-lake nutrient enrichment experiments designed to decide whether $\mathrm{C}, \mathrm{N}$, or $P$ were limiting algal production. There also exists an exceptionally complete series of lower level enrichment experiments, precise nutrient supply rate measurements, and compositional and physiological studies, which can be examined for coherence with the whole-lake results. 


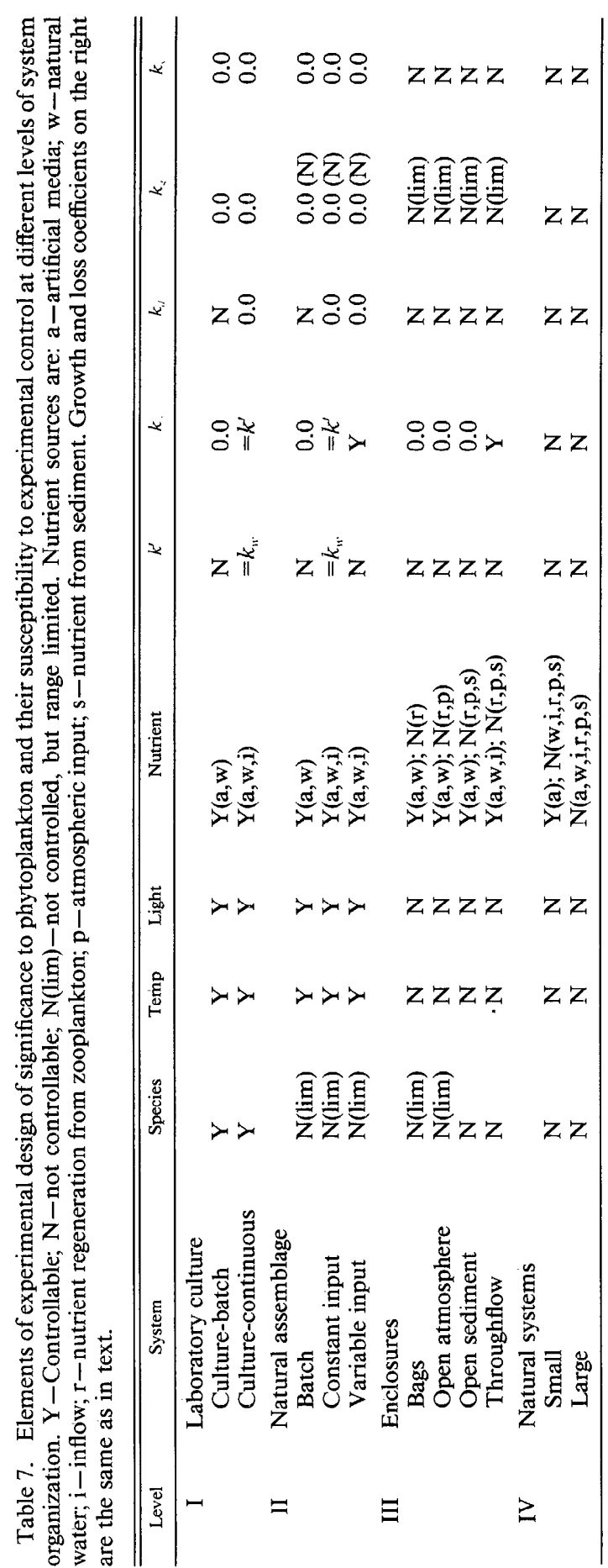

$C$ vs. $P$-In the late 1960 s an often acrimonious debate concerned the possibility that $\mathrm{C}$ rather than $\mathrm{P}$ or $\mathrm{N}$ might be the critical limiting nutrient in eutrophic freshwaters (Likens 1972). Lake 227 in the ELA (Johnson and Vallentyne 1971) was chosen for a nitrogen and phosphorus addition to determine if eutrophication could occur without the artificial addition of $\mathrm{C}$ to a natural system. Lakes of the area including Lake 227 were extremely oligotrophic, with naturally low concentrations of dissolved inorganic carbon. Sakamoto (1971) conducted a series of nutrient enrichment bioassays on natural phytoplankton assemblages from many lakes in the ELA using photosynthesis as the test response. In short-term experiments (6 h-3 d), total $\mathrm{CO}_{2}, \mathrm{Fe}, \mathrm{P}$, and $\mathrm{N}$, in decreasing order of importance, were found to limit photosynthesis, while in longer term experiments (8-20 d) P, Fe, and $\mathrm{N}$ were limiting. Sakamoto's general conclusion was that it is hard to make exact statements about the relative importance of phosphorus, nitrogen, iron, and inorganic carbon in ELA waters because of the variability in response. In June 1969, nutrient additions to Lake 227 at the rate of 0.36 mol $\mathrm{N} \mathrm{m}^{2}$ and $0.01 \mathrm{~mol} \mathrm{P} \mathrm{m}^{2}$ per year were begun. These additions stimulated chlorophyll concentration several-fold and caused a substantial depletion of total $\mathrm{CO}_{2}$ (Schindler et al. 1971). By July, total $\mathrm{CO}_{2}$ concentrations were nearly undetectable, but a series of mesocosm experiments - in situ 1-m-diameter tubes sealed to the sediments-determined that carbon availability was not limiting algal biomass (Schindler et al. 1971). In contrast, bottle bioassay experiments and diurnal primary production studies did show that the photosynthetic rate was $\mathrm{C}$ limited after midday (Schindler and Fee 1973). However, over the longer term, atmospheric invasion of $\mathrm{CO}_{2}$ into Lake 227 was more than adequate to allow large algal blooms to develop (Schindler et al. 1972). In another series of mesocosms, nutrient additions involving $C, N$, and $P$ in various combinations of various chemical forms established that $P$ was essential to any incremental growth (chlorophyll concentration), although incremental growth was always higher when a source of $\mathrm{C}$ or $\mathrm{N}$ or both was 
added in combination with $\mathrm{P}$ (Schindler et al. 1971). These mesocosm results left open the question of whether the availability of $\mathrm{C}$ or $\mathrm{N}$ could significantly modify the response of an ecosystem to $\mathrm{P}$ enrichment.

$N$ vs. $P-$ A second whole-lake nutrient enrichment experiment in Lake 226 further established the critical role of $P$ in limiting algal growth. This dual-basin lake was divided with a plastic curtain, and $\mathrm{C}, \mathrm{N}$, and $P$ werc added to onc basin while only $\mathrm{C}$ and $\mathrm{N}$ were added to the other. Only the basin receiving $P$ responded significantly in chlorophyll and primary productivity (Schindler 1975). Also, the $N$ : $P$ ratio of the added nutrients was half of that used in Lake 227. Nitrogen-fixing blue-greens were prominent in the responding Lake 226 basin, while chlorophytes dominated Lake 227 (Schindler 1975). This difference in response indicated that $N: P$ supply ratios could affect the composition of the phytoplankton community and led to further research on the role of $N: P$ supply in inducing bloomforming blue-greens.

Levine (1983) concluded that, for lakes on the Canadian Shield of the ELA, the optimal $\mathrm{N}: \mathrm{P}$ supply ratio for most phytoplankton species was between $11: 1$ and $20: 1$. Below $11: 1$, heterocystous blucgreens dominated the phytoplankton assemblages. Low $\mathrm{N}$ : $\mathrm{P}$ supply ratios were the only factor in her experiments with $10-\mathrm{m}$ diameter enclosures to induce $\mathrm{N}$-fixing algal blooms, and Flett et al. (1980) showed that the occurrence of $\mathrm{N}$ fixers in lakes was dependent on $\mathrm{N}: \mathrm{P}$ loading ratios rather than on dissolved $\mathrm{N}: \mathrm{P}$ concentration ratios, dissolved inorganic $\mathrm{N}$ concentration, or both in the ELA (Fig. 4). A whole-lake demonstration of the relation between a low $\mathrm{N}: \mathrm{P}$ loading ratio and the occurrence of $\mathrm{N}$-fixing blue-greens was initiated in Lake 227 in 1975 , when the molar ratio of $N: P$ in the added fertilizer was reduced from about 30 : 1 to $11: 1$ while the loading rate of $P$ was held constant. The change in loading ratio induced the appearance of N-fixing bluegreens in the lake for the first time (Schindler 1977), and their abundance increased in subsequent years (Fig. 5; Schindler 1985). This experiment illustrated that the response time of a natural system to overcome

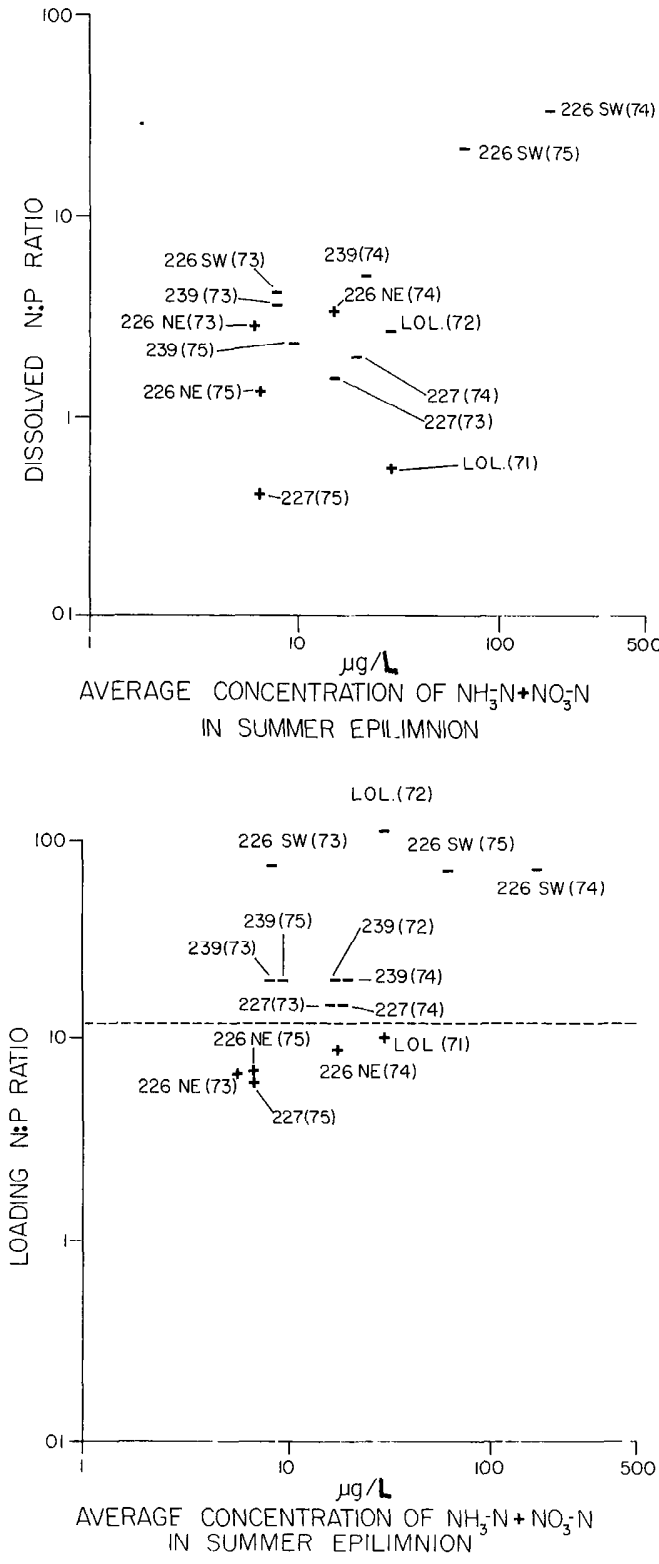

Fig. 4. Occurrences of blue-green $\mathrm{N}$ fixers ( + indicates presence; - indicates absence) in ELA lakes superimposed on plots of the dissolved (above) and loading (below) $\mathrm{N}: \mathrm{P}$ weight ratios (dissolved inorganic $\mathrm{N}$ : total dissolved $\mathrm{P}$ ) vs. average dissolved inorganic nitrogen concentrations of the summer cpilimnion of each lake (from Flett et al. 1980). Each point is labeled with the ELA lake number and the number of samples analyzed in parentheses. 


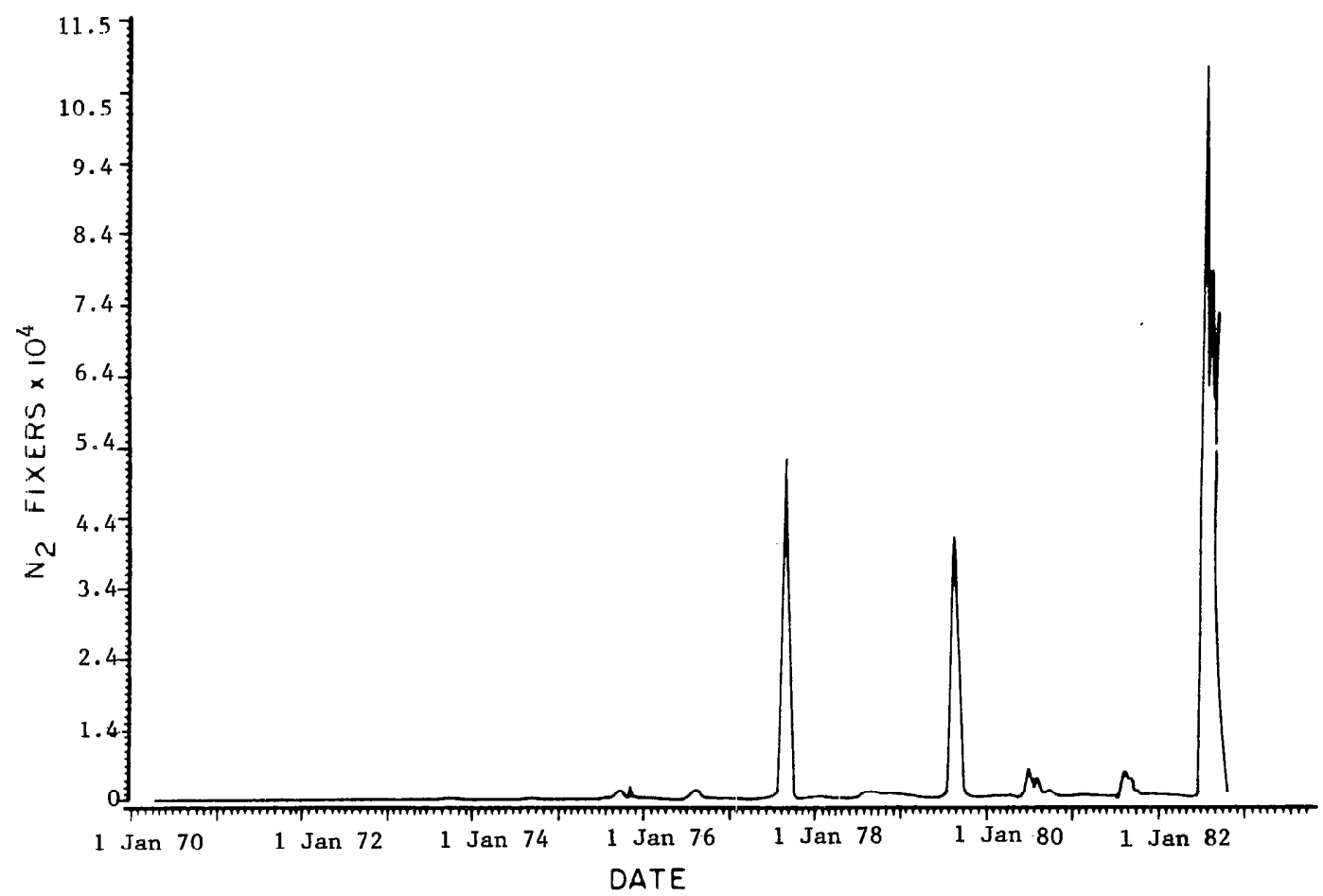

Fig. 5. Biomass ( $\mathrm{mg} \mathrm{m}^{-3}$ wet $\mathrm{wt}$ ) of $\mathrm{N}$-fixing blue-greens in the epilimnion of ELA Lake 227 , illustrating how this group was stimulated after the $\mathrm{N}: \mathrm{P}$ ratio in input was reduced from $14: 1$ to $5: 1$, by weight, in 1975 , allowing atmospheric $\mathrm{N}_{2}$ to become important in the aquatic nitrogen cycle. Dominant genera were Anabaena and Aphanizomenon (from Schindler 1985).

completely a deficiency in $\mathrm{N}$ loading was greater than $1 \mathrm{yr}$-well in excess of the time scale of most level I experiments.

Phosphorus loading-Schindler (1977) found that mean annual chlorophyll concentrations in ELA lakes were statistically dependent on the mean annual $P$ concentration regardless of the $\mathrm{N}: \mathrm{P}$ loading rate of the lake (Fig. 6). He concluded from the Lake 227 and Lake 226 experiments that $P$ ultimately limits phytoplankton concentration in lakes because these ecosystems can draw on atmospheric sources of $\mathrm{C}$ and $\mathrm{N}$ to meet their requirements. This was also demonstrated in mesocosms where blooms of $\mathrm{N}$-fixing blue-greens attained rates of primary productivity and chlorophyll concentrations comparable to those of phytoplankton with high inorganic $\mathrm{N}$ : $\mathrm{P}$ loading ratios at similar rates of $P$ loading (Levine 1983). Consequently, the mean annual chlorophyll of ELA lakes can be effectively predicted from mean annual $P$ input and a time term that accounts for water renewal (Schindler et al. 1978). In the ELA, simple arithmetic relationships can account for up to $70 \%$ of the variance in chlorophyll, while larger and more diverse groups of lakes generally render less precise relationships (Fig. 7) between $\mathrm{P}$ loading (incorporating water renewal) and chlorophyll concentration (e.g. Vollenweider 1968, 1976; Dillon and Rigler 1974; Lee et al. 1978).

Nutrient deficiency indicators - In the ELA, a suite of nutrient status indicators was consistent with the whole-lake and mesocosm experiments, which indicated that the lakes were P limited (Healey and Hendzel 1980). The degree of $P$ limitation, as measured by several indicators, was a function of the $\mathrm{N}: \mathrm{P}$ loading ratio (Fig. 8; note that the element ratios are wt/wt). Phosphorus limitation was relieved only at $\mathrm{N}: \mathrm{P}$ molar ratios $<10: 1$. Nitrogen deficiency was rare in the ELA at all times. The congruence of the nutrient status indicators 
and the ecosystem experiments at the ELA validate the use of such indicators in other natural systems. Healey and Hendzel (1980), using these indicators in a survey of northcentral Canadian lakes, found that hypereutrophic prairie lakes with dense algal blooms, some $\mathrm{N}$ fixing, were also generally $P$ limited over the whole range of chlorophyll concentrations observed ( 1 to $>350$ $\mu \mathrm{g}$ liter $^{-1} \mathrm{Chl} a$ ). Only in large, shallow, turbid lakes where light limitation occurred was $\mathrm{P}$ limitation negligible (Healey and Hendzel 1980; Hecky and Guildford 1984).

The possible sensitivity of composition ratios to detrital interference is frequently raised as an objection to their use (e.g. Tett et al. 1985). However, Healey and Hendzel (1980) found that net plankton (harvested in a $10-\mu \mathrm{m}$ net) was quite similar in several nutrient status indicators to total suspended particulates (harvested on glass-fiber filters) even in an oligotrophic, highly turbid northern reservoir with active shoreline erosion (Table 8). Although the possible role of detrital influence should be considered whenever composition ratios are used, the problem may be overrated for many waters.

\section{Marine and estuarine systems}

Marine waters are conveniently divided into estuarine, coastal, and oceanic ecosystems. These systems differ in the extent to which they are influenced by river runoff, deep ocean inputs, or both. Both of these sources, on average, meet or exceed the stoichiometric requirements for growth of many algae, but ocean waters have lower $\mathrm{N}: \mathrm{P}$ and $\mathrm{Si}$ : $\mathrm{P}$ ratios than river waters do (Table 2 ). These marine systems also differ in the impact that cultural eutrophication can have on them, with estuaries being most susceptible and the open ocean, by virtue of its volume and remoteness, being least susceptible. These systems differ from most freshwater systems in size and discreteness; i.e. boundaries between water masses are weakly defined and often variable. Consequently, controlled whole-system experiments that are possible in lakes are not feasible in these marine systems except pcrhaps in small bays with weak tidal exchange. Level III nutrient enrichment experiments are the highest level experiments done, and these have been relatively rare. Instances of multilevel nutrient

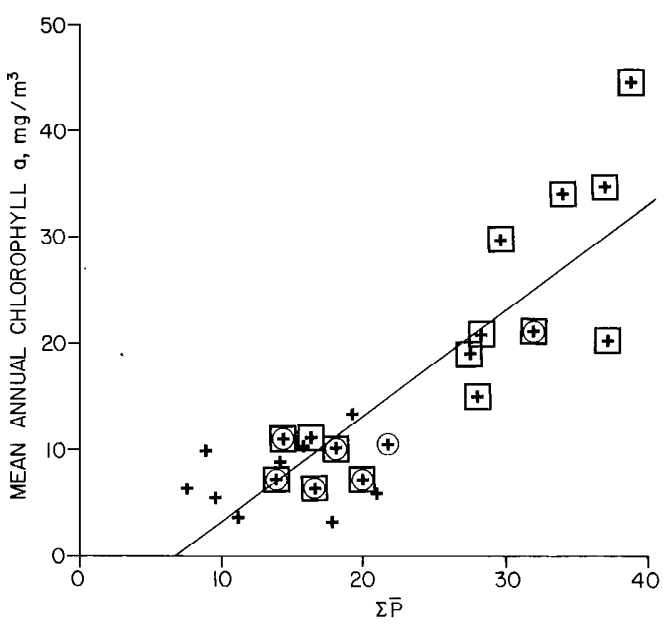

MEAN ANNUAL TOTAL PHOSPHORUS, $\mathrm{mg} / \mathrm{m}^{3}$

Fig. 6. Relationship between mean annual concentrations of total P and Chl $a$ in fertilized and unfertilized ELA lakes. All averages (pluses) are weighted for morphometry of the lakes. O-Averages for fertilized lakes where nutrients supplied by fertilizer, precipitation, and runoff were deficient in nitrogen $(\mathrm{N}: \mathrm{P}<8$ by weight). $\square-$ Averages for lakes where nutrients from the same three sources were deficient in carbon $(C$ : $\mathrm{P}<50$ by weight). Pluses without circles or squares represent lakes where $\mathrm{C}: \mathrm{P}$ and $\mathrm{N}: \mathrm{P}$ ratios in inputs are either natural or higher than natural. The linear regression equation $\mathrm{Chl} a=0.087 \Sigma \mathrm{P}-6.520$ fits the points with the correlation cocfficient $r=0.86$ (from Schindler 1977).

enrichment experiments done on the same ecosystem are even rarer.

Ryther and Dunstan (1971) presented by far the most influential paper establishing nitrogen as "the critical limiting factor to algal growth and eutrophication in coastal marine waters" (Carpenter and Capone 1983; Nixon and Pilson 1983). The basis for Ryther and Dunstan's conclusion was observational and experimental. First, the frequent observation that dissolved inorganic fixed nitrogen concentrations became undetectable while a measurable dissolved inorganic phosphate concentration remained suggested to Ryther and Dunstan, as it had to generations of marine biologists (see Nixon and Pilson 1983) before them that $\mathrm{N}$ might be more critical than $\mathrm{P}$. They pointed out that although mean seawater (primarily deep seawater) had nearly optimal nutrient ratios for phytoplankton growth, the $\mathrm{N}: \mathrm{P}$ concentration ratio of inorganic nutrients was often very low in sur- 


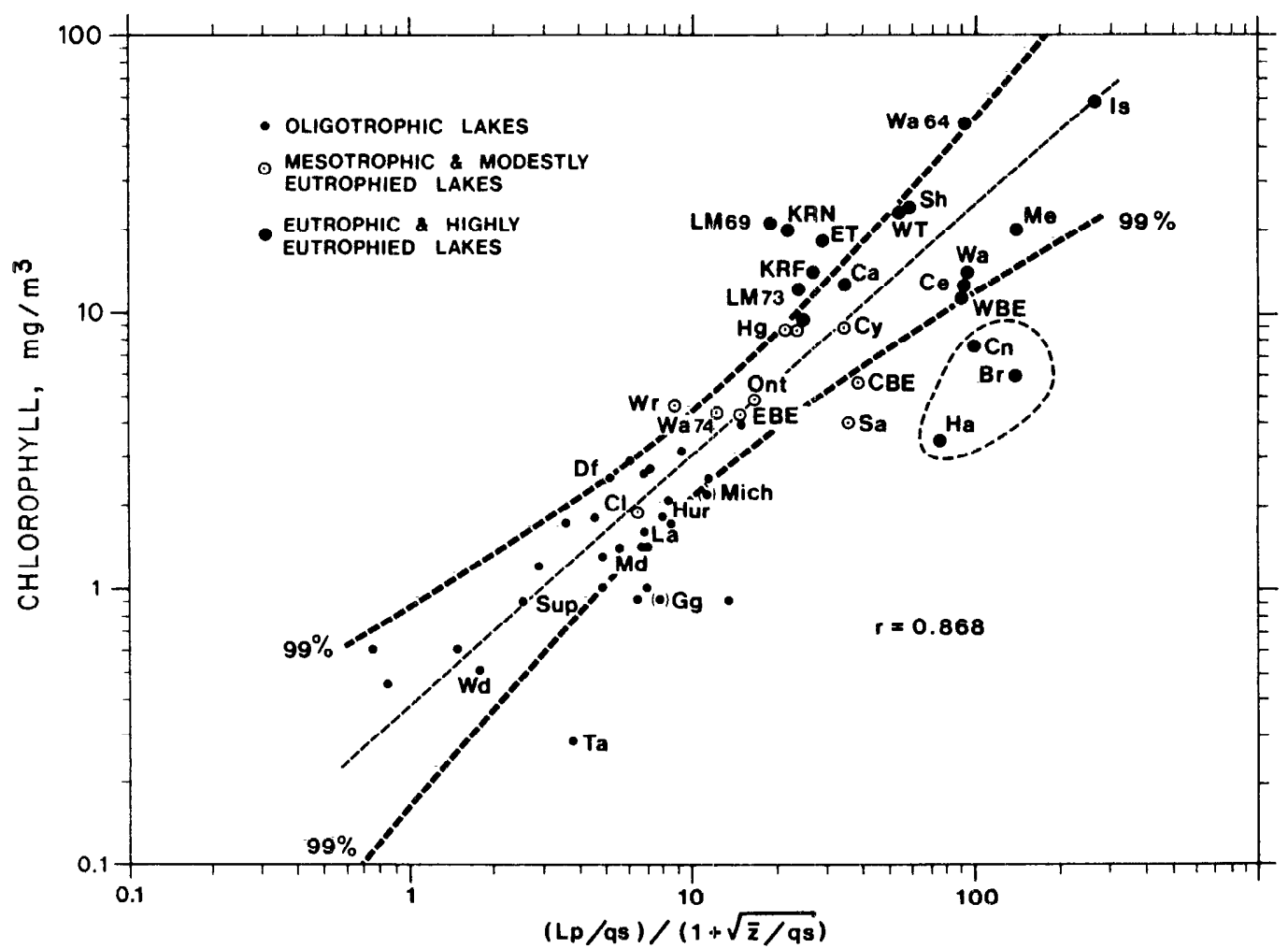

Fig. 7. Statistical relationship between average epilimnetic chlorophyll concentration and phosphorus loading characteristics (from Vollenweider 1976). $L_{p}$ is phosphorus loading $\left(\mathrm{g} \mathrm{m}^{-2} \mathrm{yr}^{-1}\right)$, gs is hydraulic loading (m $\mathrm{yr}^{-1} \mathrm{~m}^{-2}$ of lake area), and $\bar{z}$ is mean depth (m).

face ocean waters and generally less than optimum for most algae. Their original contribution to the limiting nutrient question was a series of nutrient enrichment bioassays conducted on highly polluted estuaries and coastal waters along Long Island and the New York Bight. These enrichment experiments were level I; however, the test species were organisms abundant in the natural waters. Adding only ammonia to source water consistently gave the greatest increase in cell growth, although unenriched controls and phosphate additions alone generally allowed the inoculum to grow (Fig. 9). Ryther and Dunstan (1971) invoked the low $\mathrm{N}: \mathrm{P}$ molar ratio in domestic sewage $(\sim 5: 1)$ and the more rapid regeneration of $\mathrm{P}$ from dying plankton to explain the apparent dependence of phytoplankton growth on nitrogen.

There have been many other level I and level II demonstrations (e.g. Thomas 1970; Vince and Valicla 1973; Smayda 1974;
Goldman 1976) of nitrogen causing enhanced growth relative to unenriched controlls and phosphorus additions in both coastal and open ocean waters. These conclusions are generally based on increased abundance or increased primary production (e.g. Table 9; Thomas 1969). These lower level tests are quite consistent from place to place and time to time. Unfortunately, higher level nutrient enrichment experiments are relativcly rare, so confirmations of these low-level experimental results are lacking.

The large-volume plastic sphere experiments (McCallister et al. 1961; Antia et al. 1963) of the early 1960 s can be considered large-scale level II experiments appropriate for coastal marine waters. In these experiments, filtered bottom coastal waters were introduced into large enclosures $\left(>100 \mathrm{~m}^{3}\right)$ and inoculated with $4 \mathrm{~m}^{3}$ of surface water passed through a zooplankton net. The in- 


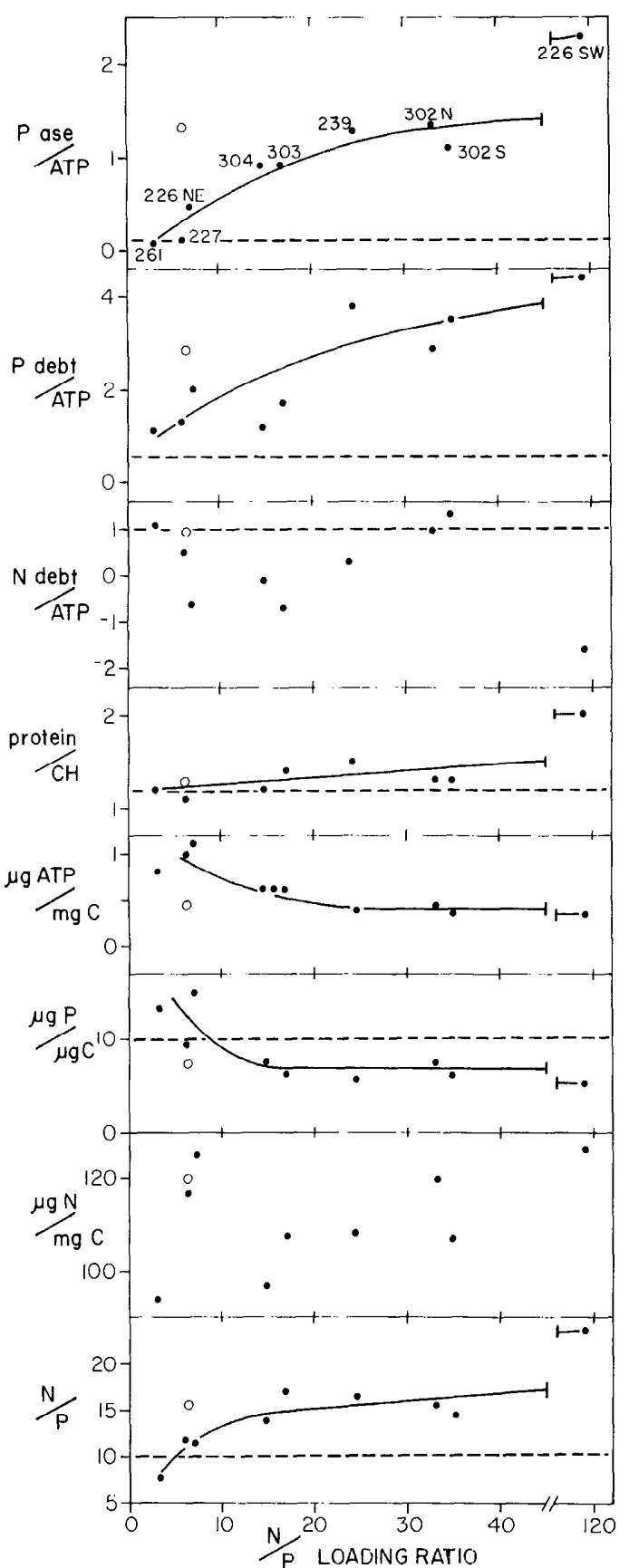

Fig. 8. Variation of several indicators of $\mathrm{N}$ or $\mathrm{P}$ deficiency in epilimnion phytoplankton with N: P (by wt) loading ratio in ELA lakes. Data points in the lower panels can be identified as to lake number by referring to the same loading ratio in the upper panel. Lake $302 \mathrm{~N}$ is plotted opposite its natural loading ratio. O-The total loading (artificial hypolimnion as well as natural surface loading) ratio of this basin. Thesc loading ratios do not include $\mathrm{N}_{2}$ fixation, which would raise the lowest tent was to follow the growth of the phytoplankton population through a growth and decay cycle. In each year, the $\mathrm{N}: \mathrm{P}$ ratio of the source water was similar at $10: 1$; a diatom bloom was stimulated and attaincd $\mathrm{Chl}$ $a$ concentrations of $45-50 \mathrm{mg} \mathrm{m}^{-3}$ around day 14-16. At the time of the chlorophyll maximum, nitrate concentrations were 0.3 $\mu \mathrm{g}$-atoms liter ${ }^{-1}$, while phosphate and silicate concentrations were similar or substantially higher. On the basis of these dissolved nutrient data, the termination of the bloom was inferred to be caused by nitrogen depletion. This inference can be questioned because the particulate composition ratios before, during, and after the bloom do not suggest severe nitrogen limitation in either experiment. At the chlorophyll maximum, the particulate $\mathrm{N}: \mathrm{P}$ molar ratio in each year was $>11$ and should have been optimal for phytoplankton growth. In fact, the particulate $\mathrm{N}: \mathrm{P}$ molar ratio was increasing throughout the formation of the blooms, suggesting that $\mathbf{P}$ was becoming relatively less available than $\mathrm{N}$ (Table 10). Termination of the diatom bloom cannot be accounted for by either $\mathrm{N}$ or P deficiency based on composition of the bloom.

Narragansett Bay-Smayda (1974) conducted level I nutrient enrichment bioassays throughout a complete year in Narragansett Bay. Subsequently, waters from this bay became the subject of level III nutrient enrichment experiments at the Marine Ecosystem Research Laboratory (MERL) (Nixon et al. 1984). Smayda concluded that $\mathrm{N}$ would be the primary limiting nutrient in the bay followed by Si and EDTA (as a surrogate for a natural chelator) over the annual cycle (Fig. 10). These level I results suggested that Narragansett Bay phytoplankton would be expected to respond to

ratios (Schindler 1977). Based on measurements of algal cultures, values above the dashed lines in the phosphatase, $\mathrm{P}$ debt, and $\mathrm{N}: \mathrm{P}$ panels indicate the presence of $P$ deficiency. In the $\mathrm{N}$ debt panel, values above the dashed line indicate $\mathrm{N}$ deficiency. In the $\mathrm{P}: \mathrm{C}$ panel, values below the dashed line indicate severe $\mathrm{P}$ deficiency. In the protein: $\mathrm{CH}$ panel, values below the dashed line indicate probable $\mathrm{N}$ deficiency. All ATP: $\mathrm{C}$ values indicate $\mathrm{P}$ deficiency and all $\mathrm{N}$ : $\mathrm{C}$, moderate $\mathrm{N}$ deficiency (from Healey and Hendzel 1980). 
Table 8. Average characteristics of net phytoplankton and total seston at five stations through Southern Indian Lake during August 1975. At each station, total seston and net phytoplankton (10- $\mu \mathrm{m}$ mesh, further purified of zooplankton as described by Healey and Hendzel 1980) were collected simultaneously. Alkaline phosphatase activity given as $\mu \mathrm{M} o$-methylfluorescein phosphate hydrolyzed ( $\mu \mathrm{g}$ ATP) ' $\mathrm{h}$ ' (from Healey and Hendzel 1980).

\begin{tabular}{|c|c|c|c|c|c|c|c|}
\hline & $P$ & $\mathbf{N}$ & $\mathrm{Chl} a$ & ATP & \multirow[b]{2}{*}{$N: P$} & \multirow{2}{*}{$\begin{array}{c}\text { Protein: } \\
\text { carbohydrate }\end{array}$} & \multirow{2}{*}{$\begin{array}{c}\text { Alkaline } \\
\text { phosphatase } \\
\text { activity }\end{array}$} \\
\hline & \multicolumn{4}{|c|}{$\left[\mu \mathrm{g}(\mathrm{mg} \mathrm{C})^{-1}\right]$} & & & \\
\hline Net plankton & 19.4 & 126 & 13.4 & 1.23 & 6.6 & 2.4 & 0.066 \\
\hline Total seston & 22.8 & 118 & 14.2 & 0.79 & 5.7 & 2.4 & 0.095 \\
\hline
\end{tabular}

nitrogen enrichment except in NovemberDecember and to Si enrichment in JuneSeptember and January-February. MERL tanks (5.0-m depth, $13.1-\mathrm{m}^{3}$ volume, with sediment bottoms, natural planktonic and benthic communities, and water renewal) were subjected to different levels of nutrient enrichment over an annual cycle (Table 11; Nixon et al. 1984). The ratio of nutrients added matched that of sewage entering Narragansett Bay. The N:P molar ratio was optimal for phytoplankton, but the addition was deficient in Si for diatoms. Chlorophyll concentrations were consistently increased at all levels of nutrient addition only in January-February and, to a lesser extent, in June-July (Fig. 11). Neither at these times nor on average was the response in chlorophyll concentration directly proportional to the added nutrients (Table 11). Nixon et al. (1984) emphasized that all of the microcosms showed large fluctuations in the biomass of phytoplankton in spite of the regular supply of nutrients and all experienced periods of very low standing crops regard- less of nutrient availability. When chlorophyll in treated MERL systems did increase relative to controls, diatoms accounted for most of the increase, and Si concentrations were reduced to extremely low levels. Also during these responsive periods, the simple introduction of bay water into the microcosms stimulated phytoplankton growth (upper left panel of Fig. 11). A JanuaryFebruary diatom bloom is a regular event in Narragansett Bay (Smayda 1974; Pratt 1965); its duration and intensity depend on winter Si concentrations and its termination is caused by grazing. Although the MERL experiments were not intended to determine which nutrient is limiting in Narragansett Bay, they demonstrate that N, P, and $\mathrm{Si}$ were not strongly limiting phytoplankton biomass over much of the annual cycle and that mean phytoplankton biomass was not proportional to nitrogen input despite the expectation inferred from level I bioassay. The results of the MERL experiments were consistent with those of Durbin et al. (1975) and Sakshaug (1977), who con-

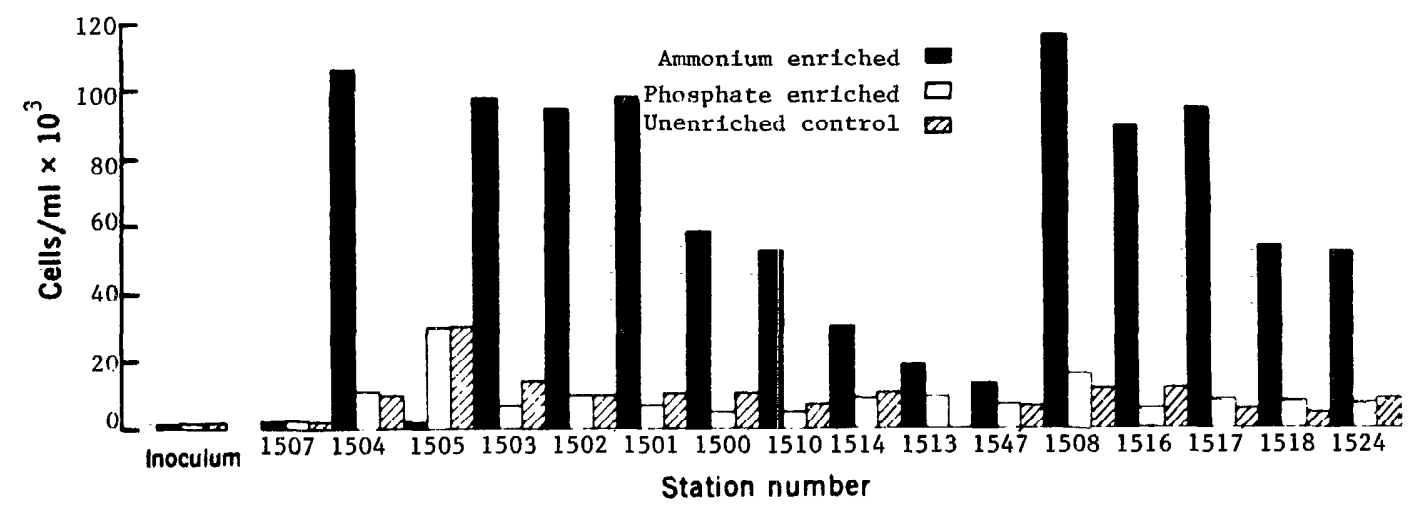

Fig. 9. Growth of Skeletonema costatum in unenriched, ammonium-enriched, and phosphate-enriched water from the New York Bight (from Ryther and Dunstan 1971). 
Table 9. Effects of nutrient enrichment on ${ }^{14} \mathrm{C}$ uptake in a seawater sample collected off Baja California in June 1964. Incubation for $5 \mathrm{~d}$ in natural light, followed by addition of $10 \mu \mathrm{Ci} \mathrm{Na}{ }^{14} \mathrm{CO}_{3}$ to 100 -ml aliquots and further incubation for $3 \mathrm{~h}$ at $12,900 \mathrm{lux}$ at $19^{\circ} \mathrm{C}$ (from Thomas 1969).

\begin{tabular}{clc}
\hline \hline $\begin{array}{c}\text { Initial nutrient concn } \\
\left(\mu \mathrm{g} \text {-atoms liter }{ }^{-1}\right.\end{array}$ & \multicolumn{1}{c}{ Enrichment } & \\
\hline $\mathrm{NO}_{3}{ }^{-}-\mathrm{N}=0.1$ & None & 1"C uptake (cpm) \\
$\mathrm{NH}_{4}{ }^{+}-\mathrm{N}=0.40$ & Complete nutrient mixture & 4,378 \\
$\mathrm{NO}_{2}{ }^{-}-\mathrm{N}=0.20$ & $+\mathrm{NO}_{3}$ & $12,579+$ \\
$\mathrm{PO}_{4}{ }^{3-}-\mathrm{P}=0.70$ & $+\mathrm{PO}_{4}{ }^{3}$ & $11,022+$ \\
$\mathrm{SiO}_{4}-\mathrm{Si}=4.3$ & $+\mathrm{Si}$ & 5,198 \\
& $+\mathrm{Fe}$ & 4,848 \\
& + trace metals & 5,501 \\
& + vitamins & 4,001 \\
& $+\mathrm{NO}_{3}{ }^{-}+\mathrm{PO}_{4}{ }^{3}$ & 3,965 \\
& $+\mathrm{NO}_{3}{ }^{-}+\mathrm{PO}_{4}{ }^{3}+\mathrm{Fe}$ & $27,432+$ \\
& & $27,485+$
\end{tabular}

cluded that the natural phytoplankton of the bay do not generally show signs of nutrient deficiency.

Nutrient loading in marine systemsNixon and Pilson (1983) further addressed the proportionality between nitrogen loading and phytoplankton biomass by relating these two for several North American estuaries and bays (Fig. 12, which includes the MERL microcosms). They concluded that the response of salt-water systems to nitrogen inputs was much less dramatic than that of lakes to the input of $P$ (note semilog scales in Fig. 12, as compared to $\log -\log$ scales in Fig. 7). Nixon and Pilson (1983) discounted the possibility that not correcting their salt-water data for flushing (as the freshwater models are) could account for the difference, since attempts to do so did not improve the relation evident in Fig. 12. They did emphasize the general lack of contemporaneous measurement of nutrient inputs and biological data for salt-water systems, which makes statistical analysis difficult. Primarily on the basis of riverine nutrient loading, various estuaries have been classified as limited by either $\mathrm{N}$ or $\mathrm{P}$ (or seasonally by either) (Jaworski 1981; Myers and Iverson 1981; McComb et al. 1981). Schindler (1981) and Smith (1984) among others (Boyle et al. 1974; Biggs and Cronin 1981) have noted that nutrients often bchave in a nearly conservative fashion in estuaries, suggesting that net biological uptake may be unimportant in these systems, which arc dominated by physical processes. Smith (1984) constructed nitrogen and phosphorus budgets for three tropical to semi- tropical embayments with rather slow flushing. He found that nitrogen fixation was a prominent feature of these environments and concluded that such systems were more likely to be limited by the availability of phosphorus than nitrogen. In general, marine systems are more difficult to budget because they are large, and the boundaries are poorly defined compared to most freshwater systems, which have relatively welldefined, nonreversing outflows and inflows. Consequently, in the marine environment the paucity of data severely restricts statistical treatment of nutrient supply relationships and investigation of modifying factors such as water residence time. Long-term historical records are also rare (Nixon and Pilson 1983). However, a 23-yr record for Narragansett Bay showed a positive correlation between plankton biomass and phos-

Table 10. Particulate composition ratios (molar) of diatom blooms in large-sphere experiments (McCallister et al. 1961; Antia et al. 1963) as populations approach chlorophyll maximum. Healey and Hendzel (1980) suggested that values of $N: P>23$ and $C: P$ $>133$ indicate $P$ deficiency and $\mathrm{C}: \mathrm{N}>8$ indicates $\mathrm{N}$ deficiency.

\begin{tabular}{|c|c|c|c|c|c|c|}
\hline \multirow{2}{*}{$\begin{array}{l}\text { Days } \\
\text { from } \\
\text { max }\end{array}$} & \multicolumn{3}{|c|}{1960} & \multicolumn{3}{|c|}{1962} \\
\hline & $C: N$ & $C: P$ & $N: P$ & $C: N$ & $C: P$ & $\mathrm{~N}: \mathrm{P}$ \\
\hline-7 & 7 & 19 & 6 & & & \\
\hline-5 & 8.5 & 17 & 5 & & & \\
\hline-4 & & & & 3.1 & 17 & 12.5 \\
\hline-2 & 4.5 & 23 & 11 & 3.2 & 22.5 & 15.5 \\
\hline 0 & & & & 3.3 & 27.5 & 18 \\
\hline 1 & 5 & 28 & 12.5 & & & \\
\hline 2 & & & & 3.9 & 31 & 18 \\
\hline 4 & 4 & 40 & 25 & 4.4 & 37 & 19 \\
\hline
\end{tabular}




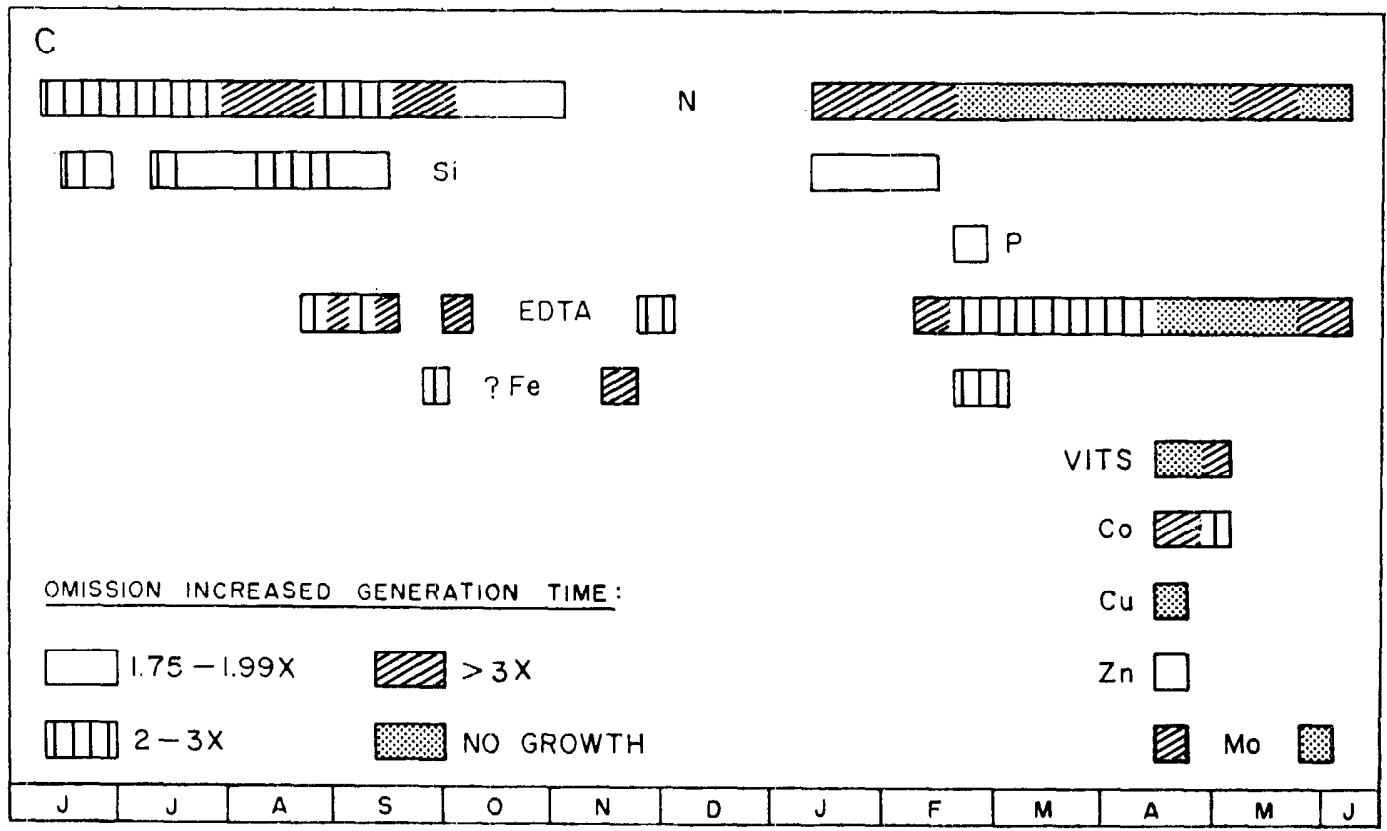

Fig. 10. Degree of limitation of Skeletonema costatum created by the omission of the indicated nutrient from a standard enrichment of Narragansett Bay water (from Smayda 1974).

phorus input but not for nitrogen or silicon input (Smayda 1985).

Particulate composition-There exists an extensive body of data on the elemental composition of marine particulate matter. Redfield $(1934,1958)$ was among the first to emphasize strongly that marine particulate matter was relatively constant over the world's oceans, with $\mathrm{C}: \mathrm{N}: \mathrm{P}$ of $106: 16: 1$ by atoms. This concept has withstood the test of time well. Copin-Montegut and Cop-
in-Montegut (1983) recently surveyed particulates from the Atlantic, Indian, and Antarctic oceans and the Mediterranean Sea. The $C: N$ ratios varied by $<20 \%$ over these waters, while the $\mathrm{C}: \mathrm{P}$ ratios were somewhat more variable (Figs. 13, 14). The CopinMonteguts did identify, using regression analysis of their large data scts, a purcly carbonaceous fraction which was generally $<20 \%$ of the particulate matter. In the remaining $80 \%$ fraction, the $C: N: P$ ratios

Table 11. Steady state nutrient concentrations expected from treatments and mean annual and maximum Chl $a$ concentrations and cocfficient of variation (\%) of the standing crop of phytoplankton in Narragansett Bay and the MERL microcosms, 1 June 1981-1 June 1982. The maximum value observed during the 1982 winterspring bloom is also shown (from Nixon et al. 1984).

\begin{tabular}{|c|c|c|c|c|c|c|}
\hline & \multicolumn{3}{|c|}{ Cuncn $(\mu \mathrm{M})$} & \multicolumn{3}{|c|}{ Chlorophyll concn (mg in ') } \\
\hline & $\mathrm{N}$ & $\mathbf{P}$ & $\mathrm{Si}$ & Mean annual & C.V. & $\operatorname{Max}$ \\
\hline Narragansett Bay & & & & 2.4 & 106 & 15.0 \\
\hline Control & & & & 4.1 & 91 & 23.3 \\
\hline Control & & & & 4.1 & 79 & 16.8 \\
\hline Control & & & & 4.7 & 112 & 24.9 \\
\hline $1 \times$ & 15.5 & 1.21 & 1.11 & 10.3 & 107 & 50.2 \\
\hline $2 x$ & 31.1 & 2.42 & 2.22 & 13.9 & 109 & 69.7 \\
\hline $4 \times$ & 62.2 & 4.84 & 4.44 & 24.4 & 121 & 91.4 \\
\hline $8 \times$ & 124.3 & 9.68 & 8.88 & 18.0 & 143 & 120.9 \\
\hline $16 \times$ & 248.6 & 19.36 & 17.76 & 35.6 & 105 & 113.9 \\
\hline $32 \times$ & 497.3 & 38.72 & 35.52 & 61.8 & 76 & 118.7 \\
\hline
\end{tabular}



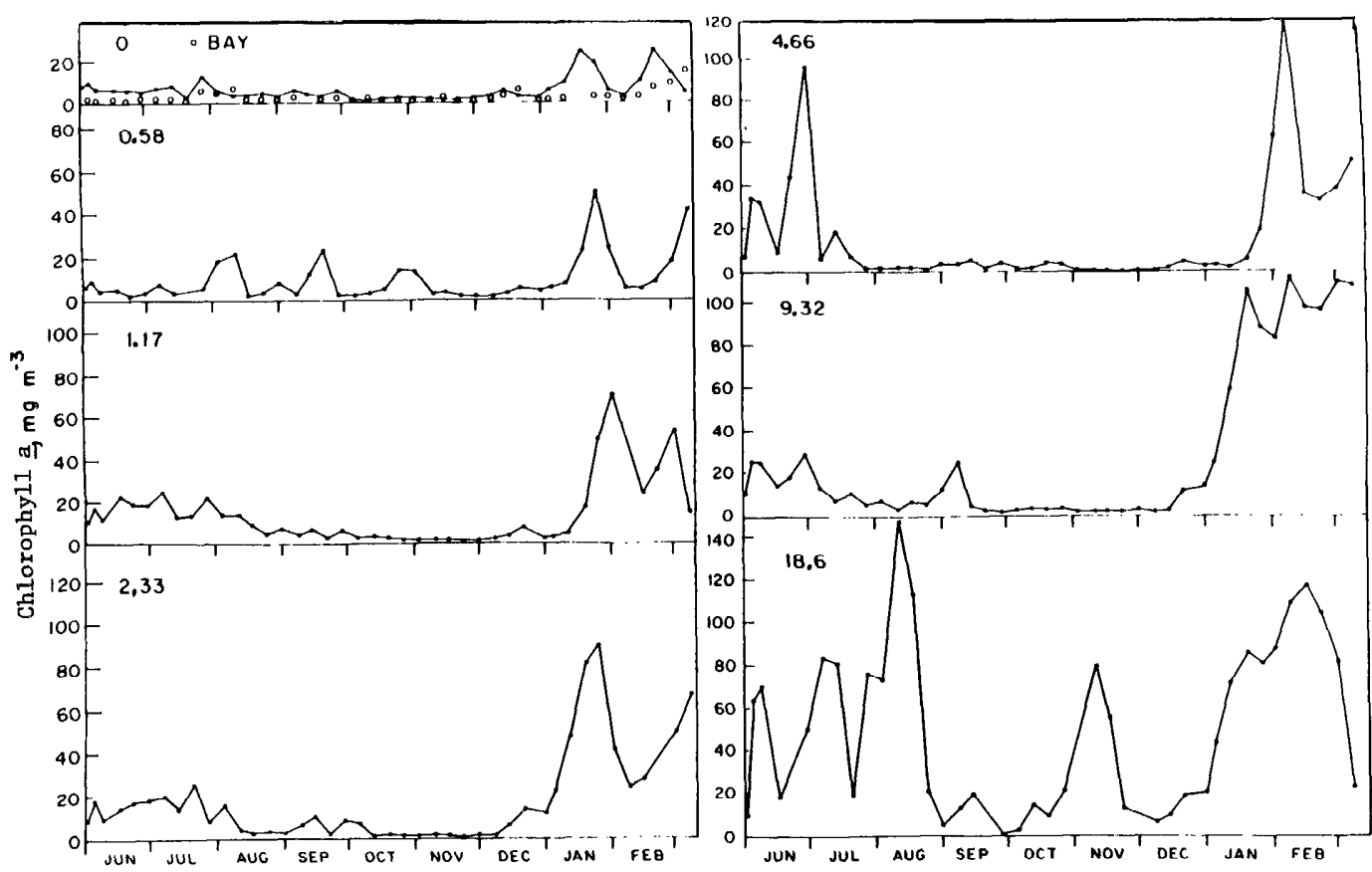

Fig. 11. Concentrations of phytoplankton Chl $a$ in Narragansett Bay (upper left) and in the MERL microcosms during the first 9.5 months of the 1981-1982 eutrophication experiment. The daily ammonia input ( $\mu$ mol liter $^{1}$ $\mathrm{d}^{-1}$ ) for each treatment is shown in the upper left of each panel (from Nixon et al. 1984).

were $103: 16: 1$-essentially the Redfield ratio. In individual samples, the carbonaceous fraction can only increase the $C: N$ or $C: P$ ratios, which would make the sample appear more deficient in $\mathrm{P}$ or $\mathrm{N}$ than the living portion. Even including this detrital contribution, very few of these samples would be considered limited either by $\mathrm{N}$ or $\mathbf{P}$ (Figs. 13, 14) using the criteria for nutrient deficiency that Healey and Hendzel (1980) applied to freshwater algae. These kinds of data have led Goldman et al. (1979) and others (Kanda et al. 1986) to suggest that the growth of open ocean phytoplankton is not strongly nutrient limited.

Despite the very low dissolved $\mathrm{N}: \mathrm{P}$ ratios (often approaching zero) that usually occur in coastal waters, the $\mathrm{N}: \mathrm{P}$ ratios in the particulate material usually approximate the Redfield ratio (Nixon 1981). Nixon (1981) offered Narragansett Bay as a specific example where the particulate $\mathrm{N}: \mathrm{P}$ ratios do not differ significantly from $16: 1$ despite frequent, extremely low dissolved $\mathrm{N}: \mathrm{P}$ ratios. Such particulate ratios would indicate that the phytoplankton are not de- ficient in $\mathrm{N}$ or $\mathrm{P}$ and would be consistent with the inconsistent response of the phytoplankton to nutrient enrichment shown in the MERL experiment. However, data on particulate composition and physiological activity have been used to infer $\mathrm{N}$ limitation in coastal New England waters (Yentsch et al. 1977) and the North Sea (Sakshaug and Olsen 1986), $P$ limitation in Norwegian fjords and coastal waters (Sakshaug and Olsen 1986), and no strong limitation by $\mathrm{N}$ or $\mathrm{P}$ in Chesapeake Bay (McCarthy 1981).

\section{Are marine and freshwater systems different?}

The evidence for the characterization of nutrient limitation in marine and freshwaters is quite different. Among limnologists, there is a general wariness of level I growth response bioassays because experience with larger systems, including intact whole ecosystems, has demonstrated that level I assays have severe limitations which make it difficult to extrapolate their results to natural systems. Level I tests can only suggest potential nutrient limitation. At least for the 


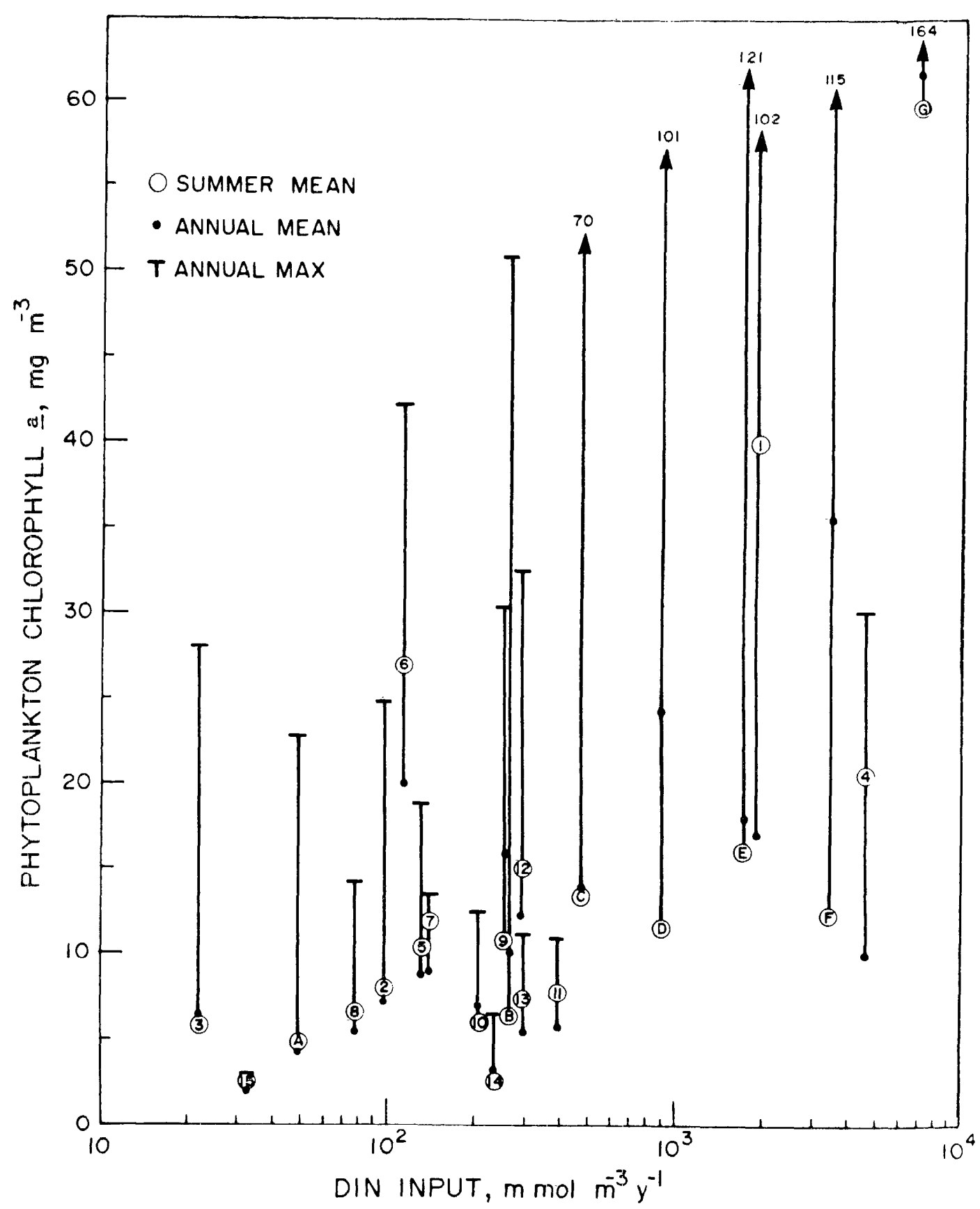

Fig. 12. Concentrations of phytoplankton $\mathrm{Chl} a$ in the midregion of various estuaries (1-15) and in the MERL experimental ecosystems (A-G) as a function of the input of dissolved inorganic nitrogen. 1-Providence River estuary, Rhode Island; 2-Narrangansett Bay, Rhode Island; 3--Long Island Sound; 4-lower New York Bay; 5-Delaware Bay; 6-Patuxent River estuary, Maryland; 7-Potomac River estuary, Maryland; 8-Chesapcake Bay; 9-Pamlico River estuary, North Carolina; 10--Apalachicola Bay, Florida; 11 - Mobile Bay, Alabama; 12-Barataria Bay, Louisiana; $13-$ N. San Francisco Bay, California; 14-S. San Francisco Bay, California; 15-Kancohe Bay, Hawaii (from Nixon and Pilson 1983). 


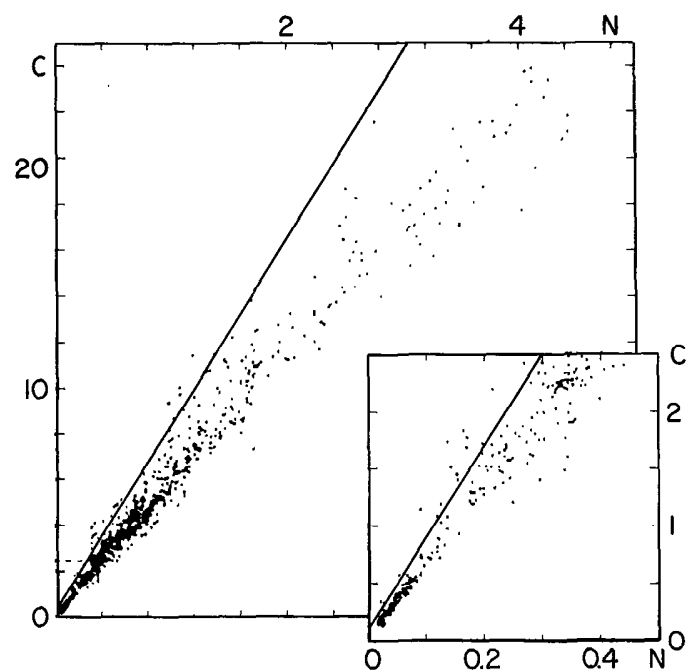

Fig. 13. Particulate organic carbon and nitrogen diagram for samples of marine particulate matter. The lower left of the plot is enlarged 5 times in the inset. Concentrations are in $\mu \mathrm{mol}$ liter $^{-1}$ (from Copin-Montegut and Copin-Montegut 1983). Solid line represents boundary for $\mathrm{N}$ deficiency (from Healey and Hendzel 1980); values above line are $\mathrm{N}$ deficient.

Experimental Lakes Area, there is a demonstrable congruence among level III system responses to nutrient enrichment, whole-lake responses to experimental enrichment, proportional response to phosphorus loading in many lakes, and compositional and physiological indicators of $P$ limitation. A similar congruence has not been found for $\mathrm{N}$ limitation in marine systems. The experimental data from which $\mathrm{N}$ limitation has been inferred were obtaincd overwhelmingly from level I and level II nutrient enrichment bioassays. Although the results are quite consistent, there are not yet confirmatory results from higher levels. Comparison of levels I and III in Narragansett Bay demonstrates that level I tests could not be extrapolated to the natural system, at least during certain times during the annual cycle. Nor is there confirmation from other lines of evidence that have proven useful in freshwater (i.e. a directly proportional response between nitrogen loading and phytoplankton biomass or consistent demonstration that marine phytoplankton are $\mathrm{N}$ deficient using compositional and physiological evidence). In fact, in semiclosed marine systems for which detailed

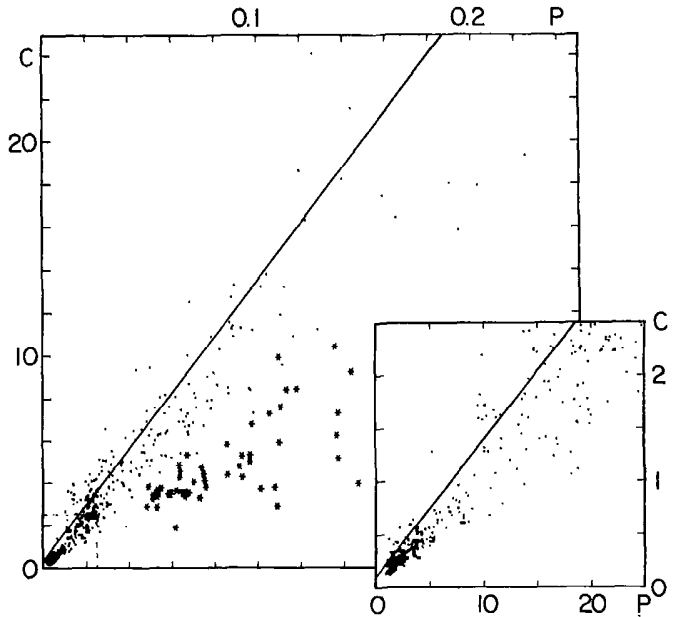

Fig. 14. Particulate organic carbon and phosphorus diagram for samples in Fig. 13. Asterisks represent surface samples from the region south and west of Kerguelen Island. Concentrations are in $\mu \mathrm{mol} \mathrm{liter}^{-1}$. In the inset, $\mathbf{P}$ units are in nmol litcr ${ }^{-1}$ (from CopinMontegut and Copin-Montegut 1983). Solid line represents boundary of $P$ deficiency (from Healey and Hendzel 1980); values above line are P deficient.

nutrient budgets can be constructed, $P$ rather than $\mathrm{N}$ has been inferred to be limiting net primary production (Smith 1984). Marine waters may differ from freshwater in the factor most frequently limiting algal growth, but the evidence that can be offered in support of $\mathrm{N}$ limitation in salt water is fundamentally weaker than the evidence for $P$ limitation in freshwater.

Research at the whole-ecosystem level in freshwaters has provided an experimental test of Redfield's (1958) hypothesis accounting for the nutrient composition of the ocean. Redfield noted the close correspondence between the proportions of $\mathrm{N}: \mathrm{P}$ in the oceans and the proportions in which they enter the biochemical cycle in the production of marine plankton. He considered three possible reasons for this coincidence: it was an accident of geochemical and evolutionary history; the organisms had adapted to the relative availability of nutrients; the organisms control the proportions of the nutrients in water. By inductive reasoning, he concluded that the last was the most likely. The whole-lake experiments mentioned above and discussed by Schindler (1977, 1985) demonstrate experimentally how or- 
ganisms can draw on the massive atmospheric source and sinks for carbon and nitrogen to maintain, on average, $\mathrm{C}: \mathrm{N}: \mathrm{P}$ ratios to meet their requirements for growth. It follows, then, that among the macronutrients $\mathrm{P}$ (or some other essential element), which does not have a large atmospheric reservoir, ultimately could control phytoplankton abundance in aquatic environments.

The rivers of the world evidently supply $\mathrm{N}$ at ratios in excess of that required to support algal growth. This fact alone explains why lakes are often $\mathrm{P}$ limited. In the cycling of river water through estuaries and coastal waters, there is a higher relative loss of fixed nitrogen than of phosphorus; thus, the deep sea has an $\mathrm{N}: \mathrm{P}$ ratio approximately optimal for algal growth (Table 2). One does not even have to invoke nitrogen fixation to account for the balanced proportions of the deep sea. Because deep-sea nutrients arise largely from regeneration of plankton, the Redfield ratio in the deep sea can be maintained only if there is not strong nutrient limitation by any one element over much of the ocean. The balanced nutrient proportions of the deep ocean do imply that if nitrogen and phosphorus were consumed by phytoplankton in Redficld proportions, then $\mathrm{N}$ and $\mathrm{P}$ would likely become limiting at nearly the same time. Therefore, it is valid to expect that $\mathrm{N}$ limitation might be more frequent in pelagic marine ecosystems than in freshwater, although this does not necessarily follow. A rigorous experimental demonstration of general $\mathrm{N}$ limitation in the ocean is lacking.

There has been a long-standing controversy about what controls phytoplankton distributions over space and time in the oceans (see Yentsch 1980). The two contesting hypotheses have been the nutrientlight hypothesis and the grazing hypothesis. Clearly both can be important (Eq. 1) and the argument is over relative importance. This argument is not as debated in the literature on lakes, where there is a more general consensus that phytoplankton arc nutrient or light limited. Phytoplankton loss terms in many lakes are often dominated by sedimentation or other nongrazing terms (Lchman and Sandgren 1985; Forsberg
1985; Tilzer 1984; Reynolds et al. 1982; Reynolds and Wiseman 1982; Jewson et al. 1981; Jassby and Goldman 1974). In contrast, grazing usually dominates loss in the oceans (Welschmeyer and Lorenzen 1985; Walsh 1976) except in very strong upwelling events (Walsh 1976). The qualitative differences in loss terms may be the fundamental difference between marine and freshwater planktonic systems, since-grazing leads to substantial regeneration, while sedimentation can rapidly strip nutrients from the photic zone. The relatively shallow water columns and comparatively low diversity of grazers in lakes may promote rapid nutrient loss compared to marine systems and ensure that nutrient limitation of phytoplankton will be common in lakes. If grazing limits phytoplankton populations most of the time in the oceans, then nutrient limitation may be a less frequent feature of marine systems.

Tropical lakes-The large tropical lakes may be an important intersection point for limnologists and oceanographers concerned with nutrient limitation of algal growth. Frequently, references in the literature (see Melack et al. 1982; Vincent et al. 1984) suggest that tropical lakes may be $\mathrm{N}$ limited. Kalff (1983), Melack et al. (1982), and Peters and MacIntyre (1976) have demonstrated $\mathrm{P}$ deficiency in several small East African lakes using level III assays and physiological and compositional measurements. With the exception of Vincent et al. (1984), $\mathrm{N}$ limitation has been inferred from the same kinds of evidence invoked for marine systems: low in situ dissolved nitrogen concentrations, especially relative to phosphorus; level I nutrient enrichment growth bioassays; and frequently low $\mathrm{N}: \mathrm{P}$ ratios in rivers. The nutrient status of the phytoplankton of the tropical great lakes is largcly unexplored.

Dependence on recycled nutrients has been offered as an explanation for the phytoplankton limitation in the ocean by nitrogen (Nixon 1981; Ryther and Dunstan 1971). Lake Tanganyika has a very low flushing rate and a deep, warm water column (Table 12), which ensure that this lake is dependent on internal cycling of nutrients. The lake has a mean algal biomass 
Table 12. Parameters related to algal production for Lakes Tanganyika and Malawi (from Hecky and Kling 1987). The flushing rate is calculated as volume divided by outflow.

\begin{tabular}{lcc}
\hline & Tanganyika & Malawi \\
\hline Flushing rate (yr) & 7,250 & 890 \\
Maximum depth (m) & 1,470 & 785 \\
Euphotic zone (m) & 30 & 50 \\
Perennial thermocline (m) & 150 & 200 \\
Chlorophyll (mg m $^{3}$ ) & 1.2 & 0.7 \\
Algal biomass (mg m $\left.{ }^{3}\right)$ & 150 & 85 \\
Primary production $\left(\mathrm{g} \mathrm{C} \mathrm{m}^{-2} \mathrm{~d}^{~}\right)$ & 0.8 & 0.7 \\
\hline
\end{tabular}

comparable to the open ocean (Hecky and Kling 1981); however, the anoxic intermediate and deep waters of the lake, unlike the ocean, have extremely low $\mathrm{N}: \mathrm{P}$ ratios (Fig. 15). If any system is poised to be $\mathrm{N}$ limited, it is Lake Tanganyika. Blooms of N-fixing Anabaena occur in the phytoplankton briefly in October-November (Hecky and Kling 1981) but are otherwise rare. A dissolved nutrient profile in April 1975 (Fig. 15) taken near the end of several months of stable stratification had low $\mathrm{N}: \mathrm{P}$ ratios in surface waters. However, high $\mathrm{N}$ : $\mathrm{P}$ ratios below the seasonal thermocline at $50 \mathrm{~m}$ indicated that sedimenting plankton and detritus were regenerating nutrients at high $\mathrm{N}: \mathrm{P}$ ratios. The lake becomes anoxic below $100 \mathrm{~m}$ at this station, and denitrification presumably produces the low $\mathrm{N}$ : $\mathrm{P}$ ratios at greater depths. The high $\mathrm{N}: \mathrm{P}$ ratios below the thermocline are not consistent with $\mathrm{N}$ limitation, but there are no data on particulate composition or other indicators of nutrient limitation for Lake Tanganyika to compare it with other aquatic systems. In Lake Malawi, a lake similar to Tanganyika in many ways (Table 12), the $C: P$ and $N: P$ ratios in particulates are high $(C: P>250: 1$ and $N: P>40: 1$; Hecky unpubl. data), indicating probablc $P$ limitation, although Moss (1969) reported a level I bioassay for Lake Malawi that indicated $\mathrm{N}$ was most likely to become limiting. If the tropical great lakes, which are dependent on internal cycling of nutrients, were shown to be more frequently $\mathrm{N}$ limited than P limited in level I bioassays but not by higher level tests or other deficiency indicators, then the apparent difference between freshwater and marine systems may be shown to be due to hydrographic and

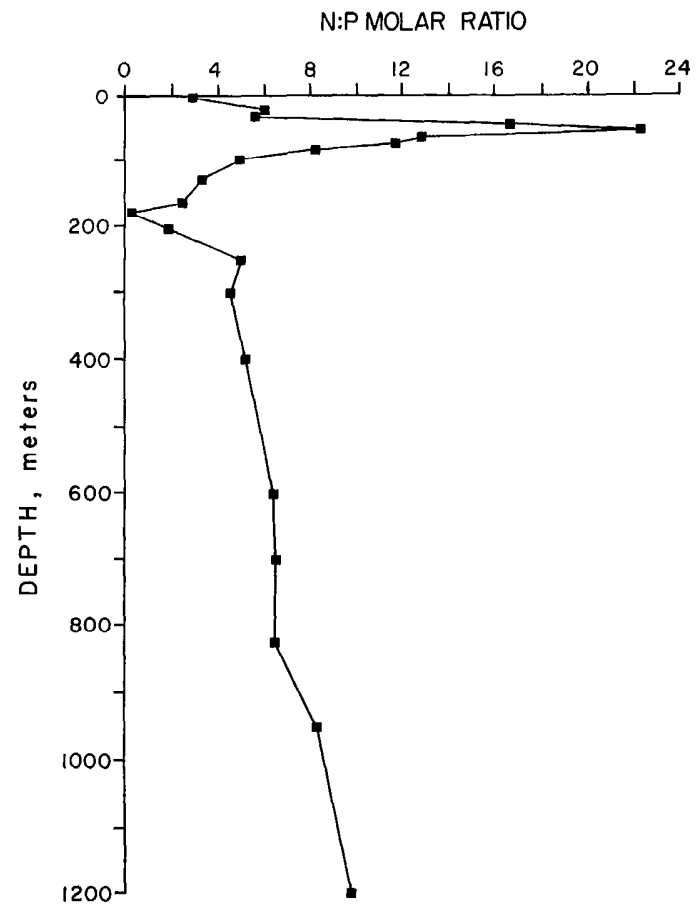

Fig. 15. N: $\mathrm{P}$ ratios of dissolved inorganic species at different depths in Lake Tanganyika, April 1975 (data from Coulter 1977).

biological features of the environment rather than to a fundamental biogeochemical difference between lakes and oceans.

Is silicon important?-Diatoms and some other groups within the Chrysophyta have an absolute requirement, not shared with other groups, for significant amounts of silicon. Total algal biomass cannot be limited by $\mathrm{Si}$, but its availability will shape phytoplankton communities. Ryther and Officer (1981) and Officer and Ryther (1980) suggest that the eutrophication of coastal waters by domestic wastes relatively poor in $\mathrm{Si}$ could lead to $\mathrm{Si}$ depletion and the elimination of diatoms from the phytoplankton communities. This process has been documented in the Laurentian Great Lakes (Schelske and Stoermer 1971; Schelske 1975; Schelske et al. 1986). Centric diatoms have bcen classed as the most desirable phytoplankton in coastal waters (Ryther and Officer 1981; Officer and Ryther 1980) because they are important in marine food chains, they do not form noxious surface blooms, and they are not toxic. Marine dia- 


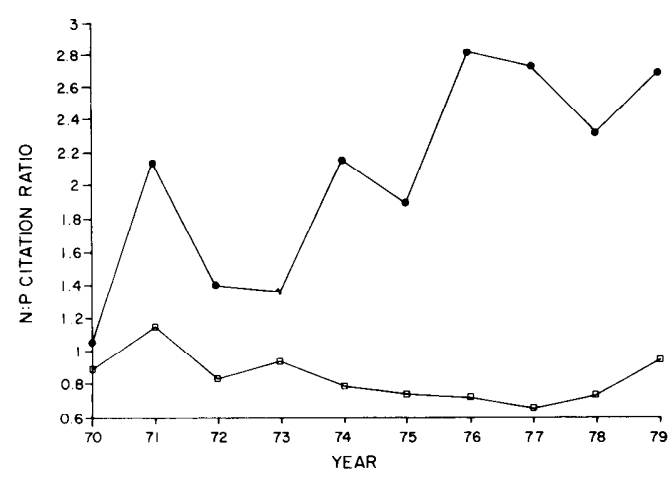

Fig. 16. Ratio of nitrogen citations to phosphorus citations in freshwater ( $\square$ ) and brackish and marine waters ( $\bullet$ ) from 1970 to 1979 , based on citations in the Bibliographic Retrieval Services Biosis Data Base.

toms often have high growth rates (Ryther and Officer 1981), and some freshwater diatoms have been shown to outcompete other algal groups for both $\mathrm{N}$ and $\mathrm{P}$ when adequate $\mathrm{Si}$ is available (Sommer 1983; Sommer and Kilham 1985; Kilham 1986; Tilman et al. 1986). Therefore, the availability of Si can channel $\mathrm{N}$ and $\mathrm{P}$ into diatoms and away from less desirable species.

The success of diatoms in competition suggests that they should have a different biomass: $P$ relationship than other groups, just as Smith (1982) has shown that the $\mathrm{N}: \mathrm{P}$ loading ratio can affect the proportional response of lake $\mathrm{Chl}: \mathrm{P}$ loading. $\mathrm{Ry}-$ ther and Officer (1981) have suggested a reinterpretation of Ryther and Dunstan (1971), in which it was inferred that the algal blooms (almost entirely the chlorophyte Nannochloris) in polluted coastal inlets were $\mathrm{N}$ limited based on level I growth bioassays. Ryther and Officer (1981) hypothesized that, in fact, the Nannochloris bloom formed and persisted because diatoms had been eliminated by Si depletion. Therefore, although the obnoxious Nannochloris bloom may have been $\mathrm{N}$ limited, the uses of the bay and especially the decline of the oyster fishery may have been limited by $\mathrm{Si}$. Dissolved $\mathrm{Si}$ becomes available to natural waters primarily through the weathering of silicate rocks. Domestic wastes have low concentrations of Si relative to $\mathrm{N}$ or $\mathrm{P}$ (table $3 \mathrm{a}$ of Ryther and Officer 1981), and the relative proportion of Si to either $\mathrm{N}$ or $\mathrm{P}$ is very low compared to the requirements of diatoms and the relative abundance of these ele- ments in natural waters (Table 2). Consequently, Si depletion can be expected to be a selective factor affecting the ecology of estuarine and coastal phytoplankton.

\section{The future: Species management}

The role of silicon in shaping phytoplankton communities illustrates the need to refine our understanding of nutrient limitation and, especially, management of all nutrient inputs in order to protect and enhance our aquatic resources. Our attempts at control of algal problems have focused primarily on how to limit an aggregate property of phytoplankton, usually biomass. The debate about $\mathrm{C}, \mathrm{N}$, or $\mathrm{P}$ in freshwater and $\mathrm{N}$ or $\mathrm{P}$ in marine waters has been motivated by a search for the best management approach to reducing algal crops. This initial response to the crisis of eutrophication was appropriate and stimulated a great advance in our knowledge of phytoplankton ecology. We now have a better appreciation of the suite of factors that can limit species abundance. In particular, we have learned that the proportion in which nutrients are loaded to a system can exert a strong influence on which algal species will thrive (Tables 4 and 5; see Kilham and Hecky 1988). In this regard, the apparent growing preoccupation with nitrogen in the marine literature (Fig. 16) may be counterproductive. A balanced approach emphasizing the interplay of various nutrients including the trace metals in shaping phytoplankton communities and their response to enrichment is required. High rates of nutrient addition are not undesirable per se, since the highest natural rates of primary production and fish production occur in naturally enriched areas such as upwellings. If we can manage the species composition of culturally eutrophicated systems to promote the growth of algal species that, in turn, increase the secondary productivity of valuable food species, then we will have solved the important nutrient limitation riddle. The key is to have nutrients accumulate as fish rather than as algae. Some natural systems accomplish this and some do not (Hecky 1984). The question for the future is whether managed aquatic ecosystems can also solve this riddle. 


\section{References}

Antia, N. J., C. D. McCallister, T. R. Parsons, K. Stephens, AND J. D. H. STRICKLAND. 1963. Further measurements of primary production using a large-volume plastic sphere. Limnol. Occanogr. 8: 166-183.

Biggs, R. B., AND L. E. Cronin. 1981. Special characteristics of estuaries, p. 3-23. In B. J. Neilson and L. E. Cronin [eds.], Estuaries and nutrients. Humana.

BOYle, E., AND OTHERS. 1974. On the chemical massbalance of estuaries. Geochim. Cosmochim. Acta 38: 1719-1728.

BRAND, L. E., W. G. Sunda, AND R. R. L. GuILlard. 1983. Limitation of marine phytoplankton reproductive rates by zinc, manganese, and iron. Limnol. Occanogr. 28: 1182-1198.

BROECKER, W. S., AND T.-H. PENG. 1982. Tracers in the sea. Eldigio. (Lamont-Doherty Geol. Obs.)

Brown, E. J., AND D. K. ButTon. 1979. Phosphate limited growth kinetics of Selenastrum capricornutum (Chlorophyccac). J. Phycol. 15: 305-311.

CARPENTER, E. J., AND D. G. CAPONE. 1983. Nitrogen in the marine environment. Academic.

Copin-Montegut, C., AND G. Copin-Montegut. 1983. Stoichiometry of carbon, nitrogen, and phosphorus in marine particulate matter. DeepSea Res. 30: 31-46.

Coulter, G. W. 1977. Approaches to estimating fish biomass and potential yield in Lake Tanganyika. J. Fish Biol. 11: 393-408.

Dillon, P. J., AND F. H. Rigler. 1974. The phosphorus-chlorophyll relationship in lakes. Limnol. Oceanogr. 19: 767-773.

Droop, M. R. 1974. The nutrient status of algal cells in continuous culture. J. Mar. Biol. Assoc. U.K. 54: $825-855$.

—_ 1977. An approach to quantitative nutrition of the phytoplankton. J. Protozool. 24: 528-531.

Durbin, E. G., R. W. Krawiec, and T. J. Smayda. 1975. Seasonal studies of the relative importance of different size fractions of phytoplankton in Narragansett Bay (U.S.A.). Mar. Biol. 32: 271-287.

Flett, R. J., D. W. SCHINDleR, R. D. HAMilton, AND N. E. R. CAMPBell. 1980. Nitrogen fixation in Canadian Precambrian Shield lakes. Can. J. Fish. Aquat. Sci. 37: 494-505.

ForSBERG, B. R. 1985. The fate of planktonic primary production. Limnol. Oceanogr. 30: 807-819.

Goldman, J. C. 1976. Identification of nitrogen as a growth-limiting nutrient in wastcwaters and coastal marine waters through continuous culture algal assays. Water Res. 10: 97-104.

—_ 1980. Physiological processes, nutrient availability, and the concept of relative growth rate in marine phytoplankton ecology. Brookhaven Symp. Biol. 31, p. 179-194. Plenum.

- AND P. M. Glibert. 1983. Kinetics of inorganic nitrogen uptake by phytoplankton, p. 233274. In E. J. Carpenter and D. G. Capone [eds.], Nitrogen in the marine environment. Academic. -, J. J. MCCarthy, AND D. G. Peavey. 1979. Growth rate influence on the chemical composition of phytoplankton in oceanic waters. Nature 279: 210-215.
Healey, F. P. 1973. Inorganic nutrient uptake and deficiency in algae. Crit. Rev. Microbiol. 3: 69113.

- 1975. Physiological indicators of nutrient deficiency in algae. Fish. Mar. Serv. Tech. Rep. 585. - 1978. Physiological indicators of nutrient deficiency in algac. Mitt. Int. Ver. Theor. Angew. Limnol. 21, p. 34-41.

. 1985. Interacting effects of light and nutrient limitation on the growth rate of Synechococcus linearis (Cyanophyceae). J. Phycol. 21: 134-146.

—, AND L. L. Hendzel. 1980. Physiological indicators of nutrient deficiency in lake phytoplankton. Can. J. Fish. Aquat. Sci. 37: 442-453.

HeCKY, R. E. 1984. African lakes and their trophic efficiencies: A temporal perspective, p. 405-448. In Trophic interactions within aquatic ecosystems. Am. Assoc. Adv. Sci. Select. Symp. Ser. 85. Westview.

—, AND S. J. GUILDFORD. 1984. Primary productivity of Southern Indian Lake before, during, and after impoundment and Churchill River diversion. Can. J. Fish. Aquat. Sci. 41: 591-604.

— AND H. J. KLING. 1981. The phytoplankton and protozooplankton of the euphotic zone of Lake Tanganyika: Species composition, biomass, chlorophyll content, and spatio-temporal distribution. Limnol. Oceanogr. 26: 548-564.

, AND - 1987. Phytoplankton of the great lakes in the western rift valley of Africa, p. 197228. In M. Munawar [cd.], Large lakes of the world. Adv. Limnol. V. 25. Schweitzer-barts'che.

Howarth, R. W., AND J. J. Cole. 1985. Molybdenum availability, nitrogen limitation, and phytoplankton growth in natural waters. Science 229: 653-655.

Hurlbert, S. H. 1984. Pseudoreplication and the design of ecological field experiments. Ecol. Monogr. 54: 187-211.

Janus, L. L., AND R. A. Vollenweider. 1981. Summary report. The OECD cooperative programme on cutrophication: Canadian contribution. Inland Waters Directorate Sci. Ser. 131-S.

JASSBY, A. D., AND C. R. GOLDMAN. 1974. Loss rates from a lake phytoplankton community. Limnol. Occanogr. 19: 745-754.

JAWORSKI, N. A. 1981. Sources of nutrients and the scale of eutrophication problems in estuaries, $p$. 83-110. In B. J. Neilson and L. E. Cronin [eds.], Estuaries and nutrients. Humana.

Jewson, D. H., B. H. RipPEy, AND W. K. Gilmore. 1981. Loss rates from sedimentation, parasitism, and grazing during the growth, nutrient limitation, and dormancy of a diatom crop. Limnol. Oceanogr. 26: 1045-1056.

Johnson, W. E., AND J. R. VALLENTYNE. 1971. Rationale, background, and development of experimental lake studies in northwestern Ontario. $\mathbf{J}$. Fish. Res. Bd. Can. 28: 123-128.

Jones, K. J., P. Tett, A. C. WAllis, AND B. J. B. Wood. 1978. Investigation of a nutrient-growth model using a continuous culture of natural phytoplankton. J. Mar. Biol. Assoc. U.K. 58: 923-941.

KALFF, J. 1983. Phosphorus limitation in some tropical African lakes. Hydrobiologia 100: 101-112. 
Kanda, J., J. Saino, AND A. Hattori. 1985. Nitrogen uptake by natural populations of phytoplankton and primary production in the Pacific Ocean: Regional variability of uptake capacity. Limnol. Oceanogr. 30: 987-999.

Kilham, P., AND R. E. Hecky. 1988. Comparative ecology of marine and freshwater phytoplankton. Limnol. Oceanogr. 33: 776-795.

KilmaM, S. S. 1986. Dynamics of Lake Michigan natural phytoplankton communities in continuous cultures along a Si: $\mathrm{P}$ loading gradient. Can. J. Fish. Aquat. Sci. 43: 351-360.

- - AND P. KILHam. 1984. The importance of resource supply rates in determining phytoplankton community structure, p. 7-28. In Trophic interactions within aquatic ecosystems. Am. Assoc. Adv. Sci. Select. Symp. Ser. 85. Westview.

LeE, G. F., AND R. A. Jones. 1981. Application of the OECD eutrophication modeling approach to estuaries, p. 549-568. In B. J. Neilson and L. E. Cronin [eds.], Estuaries and nutrients. Humana.

- - — - AND W. RAST. 1978. Eutrophication of water bodies: New insights for an age-old problem. Environ. Sci. Technol. 12: 900-908.

Lehman, J. T., AND C. D. SANDGREN. 1985. Speciesspecific rates of growth and grazing loss among freshwater algae. Limnol. Oceanogr. 30: 34-46.

Levine, S. N. 1983. Natural mechanisms that ameliorate nitrogen shortages in lakes. Ph.D. thesis, Univ. Manitoba. 354 p.

LIKENS, G. E. [ED.]. 1972. Nutrients and eutrophication. Am. Soc. Limnol. Oceanogr. Spec. Symp. 1: $328 \mathrm{p}$.

Livingstone, D. A. 1963. Chemical composition of rivers and lakes. Data of Geochemistry: U.S. Geol. Survey Prof. Pap. 440-G. 64 p.

McCallister, C. D., T. R. Parsons, K. Stephens, and J. D. H. Strickland, 1961. Measurements of primary production in coastal sea water using a large-volume plastic sphere. Limnol. Oceanogr. 6: 237-258.

MCCARTHY, J. J. 1981. Uptake of major nutrients by estuarine plants, p. 139-164. In B. J. Neilson and L. E. Cronin [eds.], Estuaries and nutrients. Humana.

McСomb, A. J., R. P. Atkins, P. B. Birch, D. M. Gordon, AND R. J. LuKATELICH. 1981. Eutrophication in the Pecl-Harvey estuarine system, Western Australia, p. 323-342. In B. J. Neilson and L. E. Cronin [eds.], Estuaries and nutrients. Humana.

Martin, J. M., AND M. Meybeck. 1979. Elemental mass-balance of material carried by world major rivers. Mar. Chem. 7: 173-206.

MelaCk, J. M., P. Kilham, AND T. R. Fisher. 1982. Responses of phytoplankton to expcrimental fertilization with ammonium and phosphate in an African soda lake. Oecologia 52: 321-326.

Meybeck, M. 1982. Carbon, nitrogen, and phosphorus transport by world rivers. Am. J. Sci. 282: $401-450$.

Moss, B. 1969. Limitation of algal growth in some central African waters. Limnol. Oceanogr. 14: 591601 .
Myers, V. B., ANd R. I. IVerson. 1981. Phosphorus and nitrogen limited phytoplankton productivity in northeastern Gulf of Mexico coastal estuaries, p. 569-582. In B. J. Neilson and L. E. Cronin [eds.], Estuaries and nutrients. Humana.

NixON, S. W. 1981. Remineralization and nutrient cycling in coastal marine ecosystems, p. 111-138. In B. J. Neilson and L. E. Cronin [eds.], Estuaries and nutrients. Humana.

—, AND M. E. Q. PILSON. 1983. Nitrogen in estuarine and coastal marine ecosystems, p. 565648. In E. J. Carpenter and D. G. Capone [eds.], Nitrogen in the marine environment. Academic. -, AND OTHERS. 1984. Eutrophication of a coastal marine ecosystem - an experimental study using the MERL microcosms, p. 105-135. In Flows of energy and materials in marine ecosystems. NATO Conf. Ser. 4, Mar. Sci. V. 13. Plenum.

OFFICER, C. B., AND J. H. RYTHER. 1980. The possible importance of silicon in marine eutrophication. Mar. Ecol. Prog. Ser. 3: 83-91.

PAerl, H. W. 1985. Microzone formation: Its role in the enhancement of aquatic $\mathrm{N}_{2}$ fixation. Limnol. Oceanogr. 30: 1246-1252.

Parsons, T. R., K. Stephens, and J. D. H. StrickLAND. 1961. On the chemical composition of eleven species of marine phytoplankters. J. Fish. Res. Bd. Can. 18: 1001-1016.

Perrry, M.J. 1976. Phosphate utilization by an oceanic diatom in phosphorus-limited chemostat culture and in the oligotrophic waters of the central north Pacific. Limnol. Oceanogr. 21: 88-107.

Peters, R. H., and S. Macintyre. 1976. Orthophosphate turnover in East African lakes. Oecologia 25: 313-319.

Petersen, R. 1975. The paradox of the plankton: $A \mathrm{n}$ equilibrium hypothesis. Am. Nat. 109: 35-49.

PRATT, D. M. 1965. The winter-spring diatom flowering in the Narragansett Bay. Limnol. Oceanogr. 10: 173-184.

RAST, W., AND G. F. LEE. 1978. Summary analysis of the North American (U.S. portion) OECD eutrophication project: Nutrient loading-lake response relationships and trophic state indices. U.S. EPA, Ecol. Res. Ser. EPA600/3-78-008.

REDFIELD, A. C. 1934. On the proportions of organic derivatives in sea water and their relation to the composition of plankton, p. 176-192. In James Johnstone Memorial Volume. Univ. Liverpool.

-1958. The biological control of chemical factors in the environment. Am. Sci. 46: 205-222.

REYNOLDS, C. S, 1984. Ecology of freshwater phytoplankton. Cambridge.

- J. M. Thompson, A. J. D. Ferguson, AND S. W. WisEman. 1982. Loss processes in the population dynamics of phytoplankton maintained in a closed system. J. Plankton Res. 4: 561-600.

- - AND S. W. WISEMAN. 1982. Sinking losses of phytoplankton in closed limnetic systems. J. Plankton Res. 4: 489-522.

RheE, G-Y. 1974. Phosphate uptake under nitrate limitation of Scenedesmus sp. and its ecological implications. J. Phycol. 10: 470-475.

- 1978. Effects of $\mathrm{N}: \mathrm{P}$ atomic ratios and ni- 
trate limitation on algal growth, cell composition, and nitrate uptake. Limnol. Occanogr. 23: 10-24.

RytheR, J. H., AND W. M. Dunstan. 1971. Nitrogen, phosphorus, and eutrophication in the coastal marine environment. Science 171: 1008-1013.

$\longrightarrow$, AND C. B. OFFICER. 1981. Impact of nutrient enrichment on water uses, p. 247-262. In B. J. Neilson and L. E. Cronin [cds.], Estuaries and nutrients. Humana.

Sakamoto, M. 1971. Chemical factors involved in the control of phytoplankton production in the Experimental Lakes Area, northwestern Ontario. J. Fish. Res. Bd. Can. 28: 123-128.

SAKSHAUG, E. 1977. Limiting nutrients and maximum growth rates for diatoms in Narragansett Bay. J. Exp. Mar. Biol. Ecol. 28: 109-123.

- , AND O. Holm-Hansen. 1977. Chemical composition of Skeletonema costatum (Grev.) Cleve and Pavlova (Monochrysis) lutheri (Droop) Green as a function of nitrate-, phosphate-, and iron-limited growth. J. Exp. Mar. Biol. Ecol. 29: $1-34$.

- _ AND Y. OLSEN. 1986. Nutrient status of phytoplankton blooms in Norwegian waters and an algal strategy for nutrient competition. Can. J. Fish. Aquat. Sci. 43: 389-396.

SCHELSKE, C. L. 1975. Silica and nitrate depletion as relatcd to rate of eutrophication in Lakes Michigan, Huron and Superior, p. 277-298. In A. D. Hasler [ed.], Coupling of land and water systems. Springer.

- AND E. F. Stoermer. 1971. Eutrophication, silica depletion and predicted changes in algal quality in Lake Michigan. Science 173: 423-424.

$\longrightarrow,-\frac{1}{-}$ G. L. FAHNENSTIEL, AND M. HAibaCH. 1986. Phosphorus enrichment, silica utilization, and biogeochemical silica depletion in the Great Lakcs. Can. J. Fish. Aquat. Sci. 43: 407-415.

SCHINDLER, D. W. 1975. Whole-lake cutrophication experiments with phosphorus, nitrogen, and carbon. Int. Ver. Theor. Angew. Limnol. Verh. 19: 3221-3231.

- 1977. The evolution of phosphorus limitation in lakes. Science 195: 260-262.

- 1981. Studies of eutrophication in lakes and their relcvance to the estuarine environment, $p$. 71-82. In B. J. Neilson and L. E. Cronin [eds.], Estuaries and nutrients. Humana.

- 1985. The coupling of elcmental cycles by organisms: Evidence from whole-lake chemical perturbation, p. 225-250. In W. Stumm [ed.], Chemical processes in lakes. Wiley.

- F. A. J. Armstrong, S. K. Holmgren, AND G. J. BRUNSKILL. 1971. Eutrophication of Lake 227, Experimental Lakes Area, northwestern Ontario, by the addition of phosphate and nitrate. $J$. Fish. Res. Bd. Can. 28: 1763-1782.

- G. J. BRUNSKILl, S. EMERSON, W. D. BroeCKER, AND T.-H. PENG. 1972. Atmospheric carbon dioxide: Its role in maintaining phytoplankton standing crops. Science 177: 1192-1194.

dissolved inorganic carbon and its use in esti- mating primary production and $\mathrm{CO}_{2}$ invasion in Lake 227. J. Fish. Res. Bd. Can. 30: 1501-1510. $\longrightarrow, \longrightarrow$, AND T. RuszczYNSKI. 1978. Phosphorus input and its consequences for phytoplankton standing crop and production in the Experimental Lake Area and in similar lakes. J. Fish. Res. Bd. Can. 35: 190-196.

SMAYDA, T. J. 1974. Bioassay of the growth potential of the surface water of lower Narragansett Bay over an annual cycle using the diatom Thalassiosira pseudonana (oceanic clone, 13-1). Limnol. Oceanogr. 19: 889-901.

- 1985. Narragansett Bay: Variability and change in environment and phytoplankton dynamics over a 23-ycar period [abstract]. Estuarics 8: 86 .

Smith, S. V. 1984. Phosphorus versus nitrogen limitation in the marine environment. Limnol. Oceanogr. 29: 1149-1160.

- W. J. Kimmerer, AND T. W. Walsh. 1986. Vertical flux and biogcochemical turnover regulate nutrient limitation of net organic production in the North Pacific gyre. Limnol. Oceanogr. 31: 161166.

SMITH, V. H. 1982. The nitrogen and phosphorus dependence of algal biomass in lakes: An cmpirical and theoretical analysis. Limnol. Oceanogr. 27: 1101-1112.

SOMMER, U. 1983. Nutrient competition between phytoplankton species in multispecies chemostat experiments. Arch. Hydrobiol. 96: 399-416.

- 1985. Comparison between stcady state and non-steady state competition: Experiments with natural phytoplankton. Limnol. Oceanogr. 30: 335346.

- AND S. S. KILHAM. 1985. Phytoplankton natural community experiments: A reinterpretation. Limnol. Occanogr. 30: 438-442.

Tett, A., S. I. Heaney, And M. R. Droop. 1985. The Redfield ratio and phytoplankton growth rate. J. Mar. Biol. Assoc. U.K. 65: 487-504.

ThомAs, W. H. 1969. Phytoplankton nutrient enrichment experiments off Baja California and in the equatorial Pacific Ocean. J. Fish. Res. Bd. Can. 26: 1133-1145

- 1970. Effect of ammonium and nitrate concentration on chlorophyll increases in natural tropical Pacific phytoplankton populations. Limnol. Oceanogr. 15: 386-394.

Tilman, D. 1977. Resource competition between planktonic algae: An experimental and theoretical approach. Ecology 58: 338-348.

- , R. Kiesling, R. Sterner, S. S. Kilham, and F. A. Johnson. 1986. Green, blue-grcen and diatom algac: Taxonomic differences in competitive ability for phosphorus, silicon, and nitrogen. Arch. Hydrobiol. 106: 473-485.

- S. S. Kilham, and P. Kilham. 1982. Phytoplankton community ecology: The role of limiting nutrients. Annu. Rev. Ecol. Syst. 13: 349372.

Tilzer, M. M. 1984. Estimation of phytoplankton loss rates from daily photosynthetic rates and ob- 
served biomass changes in Lake Constance. J. Plankton Res. 6: 309-324.

VINCE, S., AND I. VALIELA. 1973. The effects of ammonium and phosphate enrichments on chlorophyll $a$, pigment ratio and species composition of phytoplankton of Vineyard Sound. Mar. Biol. 19: 69-73.

VinCENT, W. F., W. Wurtsbaugh, C. L. VinCENT, AND P. J. Richerson. 1984. Seasonal dynamics of nutrient limitation in a tropical high-altitude lake (Lake Titicaca, Peru-Bolivia): Application of physiological bioassays. Limnol. Oceanogr. 29: 540-552.

VollenWeIDER, R. A. 1968. Water management research. OECD Paris. DAS/CSI/68.27.

___ 1976. Advances in defining critical loading levels of phosphorus in lake eutrophication. Mem. Ist. Ital. Idrobiol. 33: 53-83.

WALSH, J. J. 1976. Herbivory as a factor in patterns of nutrient utilization in the sea. Limnol. Oceanogr. 21: 1-13.

Welschmeyer, N. A., AND C. J. LoRENZEN. 1985. Chlorophyll budgets: Zooplankton grazing and phytoplankton growth in a temperate fjord and the central Pacific gyres. Limnol. Oceanogr. 30: 121.

Yentsch, C. M., C. S. Yentsch, and L. R. Strube. 1977. Variations in ammonium enhancement, an indication of nitrogen deficiency in New England coastal phytoplankton populations. J. Mar. Res. 35: $537-555$.

YeNTSCH, C. S. 1980. Phytoplankton growth in the sea-a coalescence of disciplines. Brookhaven Symp. Biol. 31, p. 17-32. Plenum.

Zevenboom, W., A. Bij de VAate, And L. Mur. 1982. Assessment of factors limiting growth rate of $O s$ cillatoria agardhii in hypertrophic Lake Wolderwijd, 1978, by the use of physiological indicators. Limnol. Oceanogr. 27: 39-52. 